\title{
POTENTIAL INFLUENCE OF URBAN SPRAWL AND CHANGING LAND SURFACE TEMPERATURE ON OUTDOOR THERMAL COMFORT IN LAGOS STATE, NIGERIA
}

\author{
Jerry N. Obiefuna (ib ${ }^{1}$, Chukwuma J. Okolie ${ }^{2}{ }^{2}$, Peter C. Nwilo ${ }^{2}$, \\ Olagoke E. Daramola (iD ${ }^{2}$, LaWrence C. Isiofia ${ }^{1}$ \\ ${ }^{1}$ Department of Architecture, Enugu State University of Science \& Technology, Enugu State, Nigeria \\ ${ }^{2}$ Department of Surveying and Geoinformatics, University of Lagos, Lagos, Nigeria
}

Manuscript received: September 3, 2020

Revised version: December 28, 2020

\begin{abstract}
Obiefuna J.N., Okоlie C.J., Nwilo P.C., Daramola O.E., Isiofia L.C., 2021. Potential influence of urban sprawl and changing land surface temperature on outdoor thermal comfort in Lagos State, Nigeria. Quaestiones Geographicae 40(1), Bogucki Wydawnictwo Naukowe, Poznań, pp. 5-23. 5 tables, 11 figs.
\end{abstract}

AвSTRACT: The continuous monitoring of the relationship between land surface temperature (LST) and land cover change is imperative for an inquiry into the potential impact of LST on human well-being, including urban outdoor thermal comfort in Lagos State, Nigeria. Using Landsat imagery, this study assessed land cover and LST changes from 1984 to 2019. Land cover was extracted, LST was determined from Landsat imageries and the land cover changes were linked to LST using the contribution index (CI). Afterwards, the universal thermal climate index (UTCI) was calculated to determine the heat stress levels. Findings confirm the presence of urban sprawl and new growth areas in previously rural Local Government Areas (LGAs) eastward, northward and westward of Lagos metropolis and in regions which lie on the fringe of the state's border with Ogun State. Also, a very strong link between high LST intensities and increasing concentration of urban areas in rapidly growing LGAs has been observed. This link further confirms the increased warming of the state, with an increase in mean LST of $2.16^{\circ} \mathrm{C}$ during $1984-2019$. The UTCI which was used to gauge the influence of LST on outdoor thermal comfort ranged from moderate to strong heat stress levels. This study helps to strengthen the case for definite policies and actions which should be aimed at achieving moderate urban development through increased urban tree canopy/green infrastructure provision and carbon sequestration activities in urban design/landscape design, in Lagos State.

KEYWORDS: Landsat imageries, land cover changes, heat stress, outdoor thermal comfort, universal thermal climate index

Corresponding author: Chukwuma J. Okolie,cokolie@unilag.edu.ng

\section{Introduction}

Urbanisation, which is the gradual shift in the residence of human populations from rural to urban areas (UN 2018), is one of the most obtrusive human actions, and gives rise to irreversible effects on the earth's surface and biosphere. These shifts in land use and territorial occupation of urban areas, as observed in Gómez et al. (2020), are topical issues at global, regional and national levels owing to their impacts on ecological and environmental systems, among others. The world has experienced its fastest rate of urbanisation, and this is especially true in developing countries (Chadchan, Shankor 2009). While 30\% of the world's population during the late 1950s 
lived in urban areas, 55\% lived in cities in 2018, a proportion which is projected to increase to $68 \%$ by 2050 (UN 2014, 2018). Expectations for the future indicate that India, China and Nigeria will account for $35 \%$ of the projected growth in the world's urban population between 2018 and 2050 (UN 2018). This growth will lead to urban expansion, an increase in demand for housing and urban infrastructure and increased pressure on environmental resources for human sustenance.

Studies have argued that urbanisation has accelerated the economic and social development of cities, globally turning them into engines of economic growth and centres of innovation, while influencing their surrounding hinterlands (De Sherbinin et al. 2007, Seto et al. 2011, Cui, Shi 2012, Ohwo, Abotutu 2015). However, urbanisation has had wide-ranging impacts on the environment, from the local scale to the global (Kim, Baik 2005, Zhao et al. 2006). Evidence suggests that it results in changes to land cover, modification of hydrologic and biogeochemical cycles, fragmentation of habitats, biodiversity reduction, alteration of local climate through modification of albedo and rapid loss of productive farmlands (Hahs et al. 2009, Radeloff et al. 2010, Seto et al. 2011). Also, urbanisation leads to increased air and water pollution, decreased water supply (Liu, Diamond 2005, Zhao et al. 2006, Cui, Shi 2012), insufficient housing, increased instances of impervious surfaces which have arisen consequent to reduction in natural vegetation, altered surface albedo and loss of ecosystem services, among others (Yuan 2008, Jago-on et al. 2009).

A notable effect of urban development is increase in temperature, particularly in densely built-up areas (Shi et al. 2015). Studies have indicated that through the phenomenon of urban heat island (UHI), urban areas are significantly warmer than their surrounding undisturbed areas and countryside. The phenomenon of UHI arises from decreased vegetation cover and from the fact that cities are constructed with highly impervious and absorptive materials such as concrete and asphalt. These materials absorb huge amounts of solar heat, thereby increasing the urban surface temperature. The increase in surface temperature leads to increased outdoor and indoor thermal discomfort, along with heat-related health risks (Uejio et al. 2011, Zhou et al. 2016, Mushore et al. 2017a, Tarawally et al. 2018). Land surface temperature (LST), which has been widely used to measure UHI, is a significant parameter in understanding the earth's surface energy balance, surface physical and chemical processes and the exchange of surface matter. LST has thus featured in many environmental and climate models (Oguz 2013, Deng et al. 2018). All over the world, the intensity of human activities, coupled with fast-paced urbanisation, is leading to alterations of the land cover and, in effect, the LST. Land cover change, including variations in surface reflectance and topography, are important indicators that influence LST (Hou et al. 2010, Obiefuna et al. 2018, Alademomi et al. 2020). Due to the physical properties of the land surface, surface temperatures are typically higher in urban areas than in vegetated areas and in the countryside; this difference is attributable to their physical properties (Nse et al. 2020). One effect of urban expansion is the increase in LST. In consequence, the link between land cover and LST needs to be understood to appreciate the ecological effects of changes in LST. Also, this understanding is necessary for an inquiry into the potential influence of LST on urban outdoor thermal comfort and human well-being.

Thermal comfort can be defined as a measure of one's physiological response to the human body's heat balance under varying environmental conditions. According to Yilmaz (2007), cited in Mushore et al. (2017b), thermal comfort or discomfort is understood to occur when $80-90 \%$ of the respondents express dissatisfaction with the prevailing temperature at a given time and location. The usage of any outdoor location for activities and leisure is partly influenced by thermal discomfort, since urban dwellers usually enjoy leisure in the thermally comfortable and conducive outdoor settings of parks and open spaces (Goshayeshi et al. 2013, Setaih et al. 2014). Furthermore, variety in urban surfaces lends to the users' exposure to varying levels of thermal comfort (Zhang et al. 2009), thereby affecting their physical and psychological performance. Outdoor thermal comfort or discomfort equally influences indoor thermal conditions (Mushore et al. 2017b). Being a subjective measure, the effects of the thermal environment on different people can vary widely, thereby making an assessment of varied users a complex task (Walls et al. 2015). Generally, scientific research on thermal 
comfort has focused on indoor/interior spaces; consequently, studies which have been undertaken so far on outdoor thermal comfort are fairly recent ones (Achour-Younsi, Kharrat 2016). In comparison with studies conducted in relation to the indoor environment, the difficulty in dealing with outdoor thermal comfort is due to the multiplicity of key variables or drivers, including climatic, personal and contributing factors that are involved. The key climatic variables affecting outdoor thermal comfort that are the most concrete and the most frequently considered include air temperature, solar exposure, mean radiant temperature, air velocity and humidity (AchourYounsi, Kharrat 2016, Jendritzky et al. 2012, Johansson et al. 2014). Understanding the interaction between these climatic variables and their influence on outdoor thermal comfort represents a complex challenge to urban designers (Walls et al. 2015, Achour-Younsi, Kharrat 2016). Recently, thermal comfort indices, which are commonly applicable in the outdoor environment to assess bioclimatic conditions for human beings, are being deployed.

The universal thermal climate index (UTCI), which was developed by the International Society of Biometeorology, is seen as one of the most comprehensive indices for calculating heat stress in the outdoor environment (Zare et al. 2018). The reason for this view is that heat stress has the potential as a heat-related health risk indicator (Napoli et al. 2018). The UTCI is a bioclimatic index which indicates the physiological heat load or stress that the human body experiences in attempting to achieve thermal equilibrium with the surrounding outdoor environment (Błażejczyk et al. 2013, Napoli et al. 2018). The UTCI is defined as the air temperature in a reference condition or environment (of 50\% humidity, still air and full shade) which results in the same strain index value as that of the reference individual's response to the real environment (Walls et al. 2015, Zare et al. 2018). According to Napoli et al. (2018), for a given combination of air temperature, wind, radiation and humidity, the UTCI can be defined as the air temperature of a reference location/environment which would lead to the same UTCI Fiala multi-node model (Fiala et al. 2012) response (shivering, sweat production, skin blood flow and rectal, skin wittedness, temperatures, mean skin and facial) in the human body as the actual environment. The reference environment is taken as a condition of calm air or a wind speed of $0.5 \mathrm{~m} \times \mathrm{s}^{-1}$ at $10 \mathrm{~m}$ above the ground, radiant temperature which is equal to air temperature with no additional thermal radiation and 50\% relative humidity (RH). Whether it is computed from an energy balance model or the UTCI Fiala multi-node model (Fiala et al. 2012), the UTCI is applicable in all climates, seasons and scales, in addition to being independent of personal characteristics such as age, gender, specific activities and clothing (Jendritzky et al. 2012, Walls et al. 2015).

According to Błażejczyk et al. (2012), the UTCI represents specific climates, weather and locations around the world much better than certain other indices. Błażejczyk et al. (2012) found the UTCI to be very sensitive to changes in ambient stimuli, including that of temperature, solar radiation, wind and humidity. In-situ measurements of air temperature and empirical observations of other meteorological parameters are required for the calculation of these indices. Generally, satellite-derived LST has not been substituted for air temperature despite their strong relationship (Mutiibwa et al. 2015, Good et al. 2017), mainly because of the difference in what both parameters measure or represent. LST is a measure of how hot the land surface (including the uppermost parts of trees and buildings) is to touch, whereas weather stations measure the air temperature just above the surface at $2 \mathrm{~m}$ height $\left(T_{2 \mathrm{~m}} ;\right.$ Good et al. 2017). However, as canvassed in Good et al. (2017), there are many parts of the globe, such as Africa (including Nigeria and Lagos State), where there are very few weather stations, thereby leading to gaps in temperature data. Good et al. (2017) also noted that earlier studies have confirmed that both LST and air temperature are generally well-coupled, with correlation coefficients being in the range of 0.6-0.8. LST and air temperature are most tightly coupled over highly vegetated surfaces when insolation is low at high latitude. In another study, Choi et al. (2020) assessed the correlation between air temperature and LST in some cities of South Korea. The result of their validation showed a high correlation of 0.9 between both parameters. Mutiibwa et al. (2015) had earlier argued that this relationship varies with atmospheric, seasonal and geographic changes. Nevertheless, they maintain the two 
remain coupled even in the presence of greater differences. This coupled relationship has therefore brought about an increase in studies which attempt to fill in the gaps in air temperature data sets with satellite LST data (Chen et al. 2015, Good 2015, Oyler et al. 2015, Parmentier et al. 2015, Janatian et al. 2016). Ultimately, the results in Good et al. (2017) presented a justification for increased use of LST data as an independent variable and to augment air temperature data in climate and weather science.

In a similar vein, Mushore et al. (2017b) canvassed persuasively for the use of Landsat medium-resolution thermal datasets to understand and map thermal comfort patterns in data-scarce cities of developing countries, where scarcity of in-situ observations may constrict such analysis. In their study of the effect of seasonal land cover changes on outdoor human thermal comfort in Harare, Zimbabwe, they concluded that Landsat 8 data detects seasonal land use/land cover and thermal discomfort changes with high accuracy. Similarly, in an earlier study, Wei-Wu et al. (2004), cited in Mushore et al. (2017b), determined outdoor thermal discomfort, with air temperature obtained from LST and RH derived from normalised difference vegetation index (NDVI), using Landsat 5 Thematic Mapper (TM) and Landsat 7 Enhanced Thematic Mapper (ETM+) imageries. Their study indicated that outdoor thermal comfort/discomfort can be modelled as a function of air temperature and $\mathrm{RH}$, both being derived from surface temperatures which are retrieved from thermal bands of Landsat. Along with Mushore et al. (2017b), some earlier studies (Cheng, Ng 2006, Widyasamratri et al. 2013, Polydoros, Cartalis 2014) have shown that LST retrieved from remote sensing is highly correlated with air temperature, thereby enabling estimation of air temperature from space-borne remote sensing of surface temperature.

In a previous study by Nwilo et al. (2012), a trend of changing LST within Lagos State, and in particular Lagos Metropolis, between 1984 and 2006 was established. Similarly, Obiefuna et al. (2018) followed up this study by tracking the dynamics of LST with land cover changes between 1984 and 2015 in Lagos Metropolis. Despite these studies, Ojeh et al. (2016) had earlier lamented the dearth of UHI studies both in tropical and Nigerian cities and emphasised particularly on the absence of consideration of UHI effects in the Lagos State Climate Change Policy document of 2012-2014. Also, they equally lamented that there were only a few studies that addressed the effects of synoptic observations of UHI with remote sensing data, in Africa's most urbanised coastal city of Lagos and in Nigeria generally. With the influence of continuing global warming coupled with unrestrained urban sprawl, continuous monitoring which is aimed at generating reliable estimates of LST and land cover changes is crucial for appropriate management and policy actions at the state level. Such monitoring can ensure more orderly growth and well-being of residents. This study, therefore, updated the investigation of changes in LST and land cover between 1984 and 2019 to determine their current spatial distribution and the continued relationship between them. As part of the response to the call for investigation of the effects of UHI on the thermal comfort and health of Lagos inhabitants by Ojeh et al. (2016), this study also inquired into the possible influence of changing LST on the outdoor thermal comfort of inhabitants of the state and metropolis.

\section{Materials and methods}

\section{Study area}

The study area is Lagos State, Nigeria (Fig. 1) with a geographic extent spanning longitudes $2^{\circ} 40^{\prime \prime}-4^{\circ} 20^{\prime \prime} \mathrm{E}$ and latitudes $6^{\circ} 20^{\prime \prime}-6^{\circ} 42^{\prime \prime} \mathrm{N}$. The state is located on the south-western tip of Nigeria, abutting the Atlantic Ocean. It is bound to the north and east by Ogun State, to the west by the Republic of Benin, and to the south by the Atlantic Ocean. The creeks and lagoons which characterise the state are part of the barrier-lagoon complex which covers the entire coastline for about $200 \mathrm{~km}$ eastward, from the border with Nigeria/the Republic of Benin in the west to the border with Ogun State in the east (Ibe 1988). These comprise Badagry Creek (which is the longest), Port Novo Creek, Lighthouse Creek and Ologe Lagoon, all in the west, and Lagos and Lekki Lagoons in the east. All these connect to the Atlantic Ocean through Commodore Channel, which is the only inlet/ outlet to Lagos Harbour and the only western connection to Lagos Lagoon. Created in May 


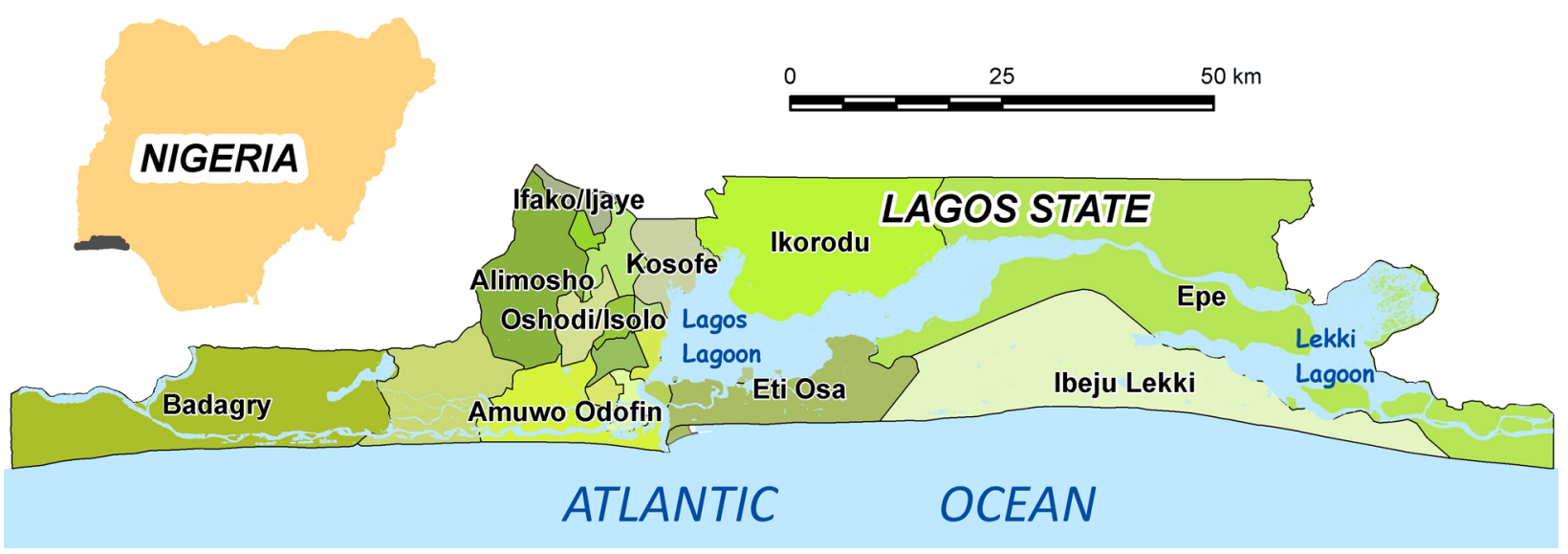

Fig. 1. Map of the study area.

1967, Lagos State, occupying an area of $3,632 \mathrm{~km}^{2}$ of land and water, is home to Lagos Metropolis. Lagos Metropolis is a former federal capital and the current economic capital of Nigeria; it is recognised as one of the mega-cities of the world and has had a rapid population growth since 1970 (UN 2014). The state has experienced unabated urban sprawl, which has resulted in the metropolis growing into the surrounding towns and villages to practically become a onecity state. The twenty Local Government Areas (LGAs) in Lagos State include the following: Agege, Ajeromi-Ifelodun, Alimosho, AmuwoOdofin, Apapa, Badagry, Epe, Eti-Osa, Ibeju/ Lekki, Ifako-Ijaiye, Ikeja, Ikorodu, Kosofe, Lagos Island, Mainland, Mushin, Ojo, Oshodi-Isolo, Shomolu and Surulere.

\section{Datasets}

For this study, three scenes of satellite imageries from Landsat 5 TM, Landsat 7 ETM+ and Landsat 8 Operational Land Imager (OLI)/ Thermal Infrared Sensor (TIRS) were acquired (USGS 2020). To maximise coverage and due to presence of cloud cover on some of the Landsat imageries, a combination of scenes (191/055, $190 / 056$ and 191/056) was done to form image composites for the state at three average periods, namely 1984, 2001 and 2019. The scenes used for land cover classification covered the epochs of TM (1984-1985), ETM+ (2001/2002) and OLI $(2018 / 2019)$, whereas the scenes used for LST retrieval covered the epochs of TM (1984/1985), ETM+ (2000-2001) and OLI (2018/2019). All images were captured by the sensors between
December 18 and January 30 in their respective years and between 09:24 AM and 10:03 AM GMT (10:24 AM and 11:03 AM Nigerian time). These capture dates were within the dry season period of the country. The Landsat imageries were geometrically corrected by the United States Geological Survey (USGS) and ortho-rectified to Level 1 (Tatem et al. 2006, Gutman et al. 2013). The alignment with the boundary of Lagos State was satisfactory. A list of town and community locations (including coordinates) was obtained from the National Population Commission (NPopC). All datasets were harmonised into the Universal Transverse Mercator (Zone 31N) coordinate system on the WGS84 datum to avoid conflict of datum and positional aberration in subsequent processes.

\section{Land cover and LST}

In the extraction of land cover, the first step involved a preliminary interpretation of the Landsat imageries. This interpretation categorised the study area land cover into five classes, namely bare land, built-up area, wetland forest, mixed forest and water body. Next, a step-bystep process of training class selection, based on the spectral signatures of each class and together with ancillary data, was done on ENVI 5.0 software. ENVI image analysis software by L3Harris Geospatial is used extensively by Geographic Information System (GIS) professionals and remote sensing scientists for image processing and analysis. Thereafter, the image was subjected to supervised classification using the parallelepiped technique. The parallelepiped classifier adopts a 
simple decision rule for classifying multispectral imagery. In the image data space, the decision boundaries form a n-dimensional parallelepiped classification, which is based on a standard deviation (SD) threshold from the mean of each selected spectral class (Richards 1999, Harris Geospatial 2020). After classification, the feature classes were transferred to ArcGIS 10.4 for editing and calculation of geometry. ArcGIS is a GIS software developed by the Environmental Systems Research Institute (ESRI) and is used for working with maps and geographic information analysis.

Following Oguz (2013), Ferrelli et al. (2015) and Obiefuna et al. (2018), the LST was derived using a single channel method. The first step involved the conversion of the imagery digital numbers (DNs) to spectral radiance. The conversion formula for Landsat TM thermal Band 6, ETM Band 6.1 is given by Zareie et al. (2016), as follows:

$$
\begin{aligned}
L_{\lambda} & =\left(\frac{(L M A X-L M I N)}{(Q C A L M A X-Q C A L M I N)}\right) \times \\
& \times(Q C A L-Q C A L M I N)+L M I N
\end{aligned}
$$

where:

- $L_{\lambda}$ is spectral radiance at the sensor's aperture (Watts $\left./\left(\mathrm{m}^{2} \times \mathrm{sr} \times \mu \mathrm{m}\right)\right)$,

- QCAL is the quantised calibrated pixel value in $\mathrm{DN}$,

- LMIN is the spectral radiance scaled to QCALMIN,

- $\angle M A X$ is the spectral radiance scaled to $Q C A L$ $M A X$,

- QCALMIN is the minimum quantised calibrated pixel value (corresponding to LMIN) in $\mathrm{DN}$,

- QCALMAX is the maximum quantised calibrated pixel value (corresponding to LMAX) in DN.

The conversion for TIRS Band 10 follows Eq. (2) by USGS (2015), and is expressed as the following:

$$
L_{\lambda}=M_{L} \times Q C A L+A_{L}
$$

where:

- $M_{L}$ is the radiance multiplicative scaling factor for the band,
- $A_{L}$ is the radiance additive scaling factor for the band.

After obtaining the spectral radiance, the top-of-atmosphere (TOA) brightness temperature was then calculated according to Dewan and Corner (2012), Zareie et al. (2016), Hamoodi et al. (2019) and Guha et al. (2020) to be the following:

$$
\mathrm{T}=\mathrm{K}_{2} / \log \left(1+\mathrm{K}_{1} / L_{\lambda}\right)
$$

where:

- $T$ is the TOA brightness temperature ( $\operatorname{deg} \mathrm{K})$,

- $K_{1}\left(\mathrm{~W} \times \mathrm{cm}^{-2} \times \mathrm{sr}^{-1} \times \mu \mathrm{m}^{-1}\right)$ and $\mathrm{K}_{2}(\operatorname{deg} \mathrm{K})$ are pre-launch calibration constants.

The brightness temperature was converted to LST in Kelvin using Eq. (4) (Hamoodi et al. 2019, Ullah et al. 2019). The LST in Kelvin was subsequently converted to Celsius.

$$
S_{T}=\frac{T}{1+(\lambda \times T / \rho) \log \varepsilon}
$$

where:

- $S_{T}$ is the LST (deg K),

- $\lambda$ is the wavelength of emitted radiance $(11.5 \mu \mathrm{m})$,

- $\varepsilon$ is the land surface emissivity (typically 0.95 ),

- $\rho=h \times c / \sigma=1.438 \times 10^{-2} \mathrm{mK}(\sigma-$ Boltzmann constant $=1.38 \times 10^{-23} \mathrm{~J} \times \mathrm{K}^{-1}, h-$ Planck's constant $=6.626 \times 10^{-34} \mathrm{Js}$ and $c$ - velocity of light $=2.998 \times 10^{8}{\mathrm{~m} \times \mathrm{s}^{-1}}^{-1}$.

An inventory of the LST and corresponding land cover were created for the state. To do this, the 'extract values to points' tool in ArcGIS Spatial Analyst was used to extract the temperature values on the LST maps coinciding with several community locations. The extraction appended the values to the attribute tables of the point shapefiles. Next, the 'select by location' tool was used to select the communities within each LGA, and the LST distribution across the communities was summarised within the attribute tables to derive the mean LSTs. The same selection operation was repeated to summarise the LST based on the land cover categories. Due to the presence of cloud cover on some of the imageries, the sample points for LST comparison were extracted from the cloud-free areas of the imageries. The descriptive statistics of the land cover and LST were explored by calculating the parameters: mean, SD and standard error (SE). 


\section{Contribution index}

The urban expansion was further linked to LST through the contribution index (CI), as suggested by Tarawally et al. (2018). The effect of a specific land cover in warming or cooling an area depends on the land cover type and the proportion of the total area it occupies (Odindi et al. 2017, Tarawally et al. 2018). This warming or cooling effect is quantified using the $\mathrm{CI}$, which links the spatial structure and temporal changes in land cover to LST intensities. Thus, the CI for each land cover class is computed as follows:

$$
C I=D t \times S
$$

where:

- $D t$ is the difference between the average or mean temperature of the entire study area and the average or mean of the land cover class,

- $S$ is the proportional area of the land cover type which equals the ratio of the area occupied by the land cover class to the total study area.

Positive CI values indicate the extent to which the land cover contributes to raising the temperature of the study area. Similarly, negative values suggest LST mitigation values.

\section{Universal Thermal Climate Index}

Calculating the UTCI requires readings or measurements of various parameters; these include air temperature, wind speed (which should

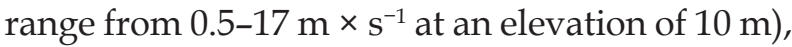
solar radiation (from full shade to full sun) and RH (Walls et al. 2015, Zare et al. 2018). The UTCI can be calculated online for any location using the UTCI Calculator (Bröde 2020) and the Heat Stress Index Calculator (Climate CHIP 2020). Both the UTCI and the WetBulb Globe Temperature
(WBGT) are calculated at Climate CHIP (2020). As observed by Good et al. (2017), many areas in the world, in particular Africa, including Nigeria, are not covered by weather stations. In such cases, as in Lagos State which has only one station, Good et al. (2017) recommended that LST can serve as a proxy to air temperature, since on the basis of earlier studies and theirs, it has been established that both are highly correlated. Therefore, relying on this recommendation, the mean LSTs derived on 30 January 2019 for various LGAs in the state were coupled with Lagos State's historical weather for that date to calculate the UTCI online for the state. This was done with the UTCI interactive calculator developed by the UTCI development team (Bröde 2020) and with the UTCI and WBGT heat stress calculator provided by Climate CHIP (2020). The RH on that date was $65 \%$ while wind speed was $12 \mathrm{~km} \times \mathrm{hr}^{-1}$ or $3.33 \mathrm{~m} \times \mathrm{s}^{-1}$. As a bioclimatic index that describes a thermal condition's influence on a standardised human body (Zare et al. 2018), the range and classification of UTCI thermal sensations or stress levels have already been documented. The stress level classifications are as follows: extreme heat stress (above $46^{\circ} \mathrm{C}$ ), very strong heat stress $\left(38^{\circ} \mathrm{C}\right.$ to $\left.46^{\circ} \mathrm{C}\right)$, strong heat stress $\left(32^{\circ} \mathrm{C}\right.$ to $\left.38^{\circ} \mathrm{C}\right)$, moderate heat stress $\left(26^{\circ} \mathrm{C}\right.$ to $\left.32^{\circ} \mathrm{C}\right)$, no thermal stress $\left(9^{\circ} \mathrm{C}\right.$ to $\left.26^{\circ} \mathrm{C}\right)$, slight cold stress $\left(9^{\circ} \mathrm{C}\right.$ to $\left.0^{\circ} \mathrm{C}\right)$, moderate cold stress $\left(0^{\circ} \mathrm{C}\right.$ to $\left.-13^{\circ} \mathrm{C}\right)$, strong cold stress $\left(-13^{\circ} \mathrm{C}\right.$ to $\left.-27^{\circ} \mathrm{C}\right)$, very strong cold stress $\left(-27^{\circ} \mathrm{C}\right.$ to $\left.-40^{\circ} \mathrm{C}\right)$, and extreme cold stress (below $-40^{\circ} \mathrm{C}$ ) (Walls et al. 2015, Zare et al. 2018).

\section{Results and analysis}

\section{Analysis of the land cover and LST changes}

Table 1 presents the areal distribution of the land cover classes for 1984, 2001 and 2019,

Table 1. Areal distribution in the coverage of land cover between 1984 and 2019.

\begin{tabular}{|c|l|r|r|r|r|r|r|}
\hline \multirow{2}{*}{ S/N } & \multirow{2}{*}{ Land Cover } & \multicolumn{2}{|c|}{ Area in 1984} & \multicolumn{2}{|c|}{ Area in 2001} & \multicolumn{2}{|c|}{ Area in 2019} \\
\cline { 3 - 7 } & & {$\left[\mathrm{km}^{2}\right]$} & {$[\%]$} & {$\left[\mathrm{km}^{2}\right]$} & {$[\%]$} & \multicolumn{1}{c|}{$\left[\mathrm{km}^{2}\right]$} & \multicolumn{1}{c}{$[\%]$} \\
\hline 1 & Bare Land & 136.60 & 3.76 & 189.81 & 5.23 & 142.27 & 3.86 \\
\hline 2 & Built-up Area & 134.58 & 3.70 & 464.21 & 12.78 & 1041.88 & 28.24 \\
\hline 3 & Mixed Forest & 1708.10 & 47.02 & 1466.45 & 40.37 & 1043.05 & 29.13 \\
\hline 4 & Water Body & 761.88 & 20.97 & 748.77 & 20.61 & 714.32 & 19.36 \\
\hline 5 & Wetland Forest - including mangrove and swamps & 794.87 & 21.88 & 763.29 & 21.01 & 678.90 & 18.40 \\
\hline 6 & Cloud Cover & 96.49 & 2.66 & - & - & 17.07 & 0.46 \\
\hline & Total & 3632.52 & 100.00 & 3632.52 & 100.00 & 3637.49 & 100.00 \\
\hline
\end{tabular}




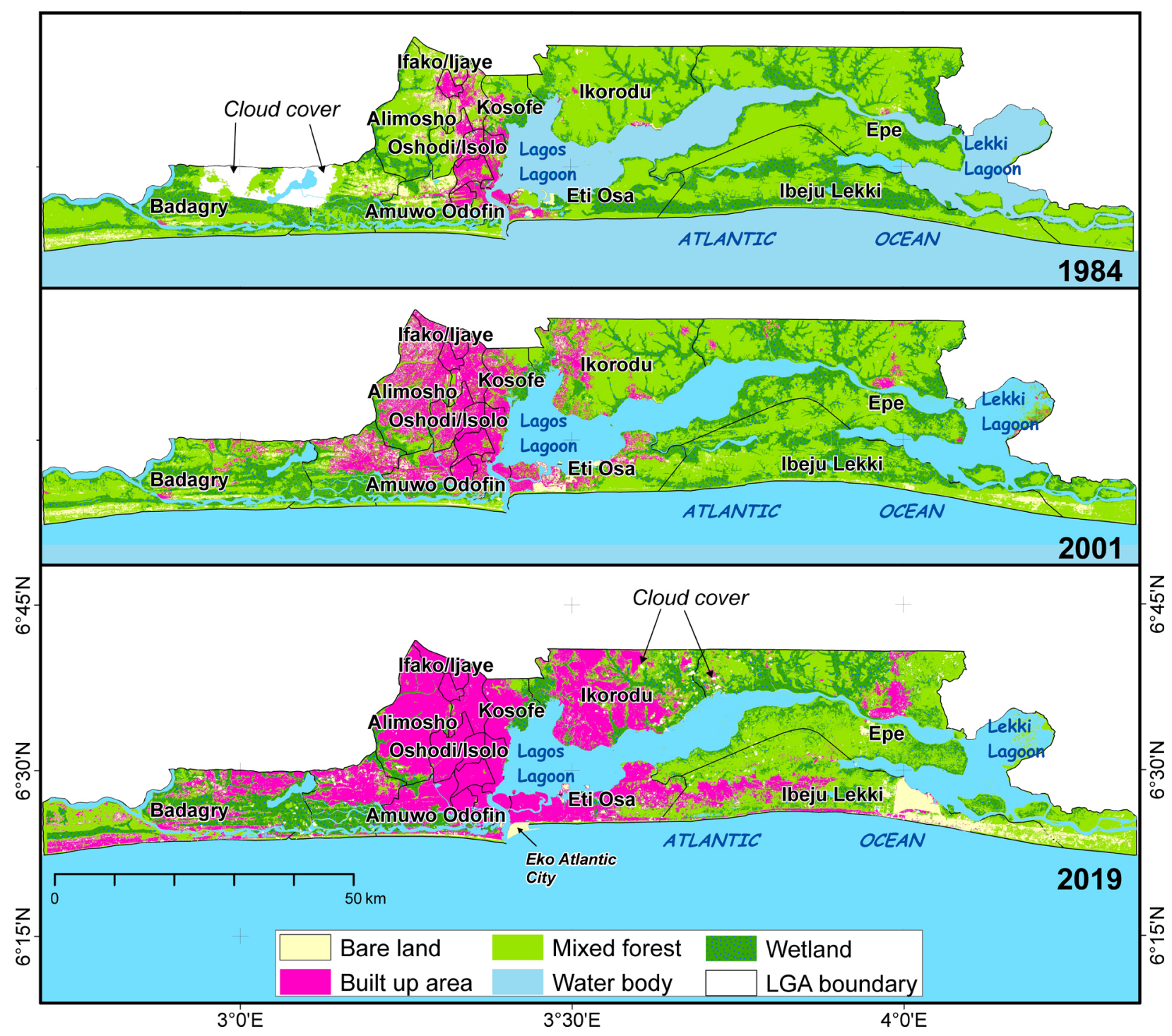

Fig. 2. Spatial variation in land cover.

respectively. Figure 2 shows the spatial variation of land cover for the three periods while Figure 3 shows a graphical illustration of the changes in land cover during 1984-2019. There was a continuous increase in the areal extent of built-up

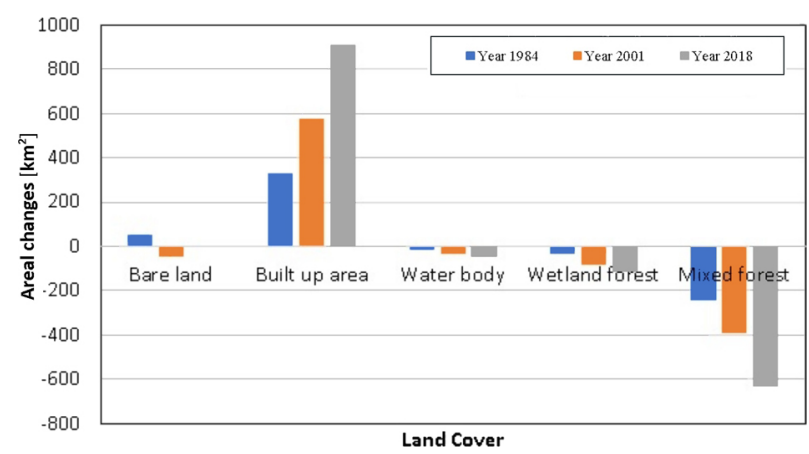

Fig. 3. Changes in land cover during 1984-2019. areas throughout the period. For example, during 1984-2001 and 2001-2019, the area of built-up areas increased at the rate of $19.39 \mathrm{~km}^{2} \times \mathrm{a}^{-1}$ and $32.09 \mathrm{~km}^{2} \times \mathrm{a}^{-1}$, respectively. Conversely, there was a continuous decrease in the extent of mixed forests, wetland forests and water bodies. For instance, during 1984-2001 and 2001-2019, mixed forests declined at a rate of $14.21 \mathrm{~km}^{2} \times \mathrm{a}^{-1}$ and $23.52 \mathrm{~km}^{2} \times \mathrm{a}^{-1}$, respectively. In the 35 years between 1984 and 2019, the yearly rates of change were as follows: bare lands $\left(+0.16 \mathrm{~km}^{2} \times \mathrm{a}^{-1}\right)$, built-up areas $\left(+25.92 \mathrm{~km}^{2} \times \mathrm{a}^{-1}\right)$, mixed forests $\left(-19.00 \mathrm{~km}^{2} \times \mathrm{a}^{-1}\right)$, water bodies $\left(-1.36 \mathrm{~km}^{2} \times \mathrm{a}^{-1}\right)$ and wetland forests $\left(-3.31 \mathrm{~km}^{2} \times \mathrm{a}^{-1}\right)$. This affirms the on-going accelerated urbanisation in Lagos State, especially within and around the metropolis, and the consequent compromise in natural 
Table 2. Areal changes in land cover within the six focus LGAs between 1984 and 2019.

\begin{tabular}{|c|c|c|c|c|c|c|c|c|c|c|c|c|}
\hline \multirow{3}{*}{ LGA } & 1984 & 2001 & 2019 & 1984 & 2001 & 2019 & 1984 & 2001 & 2019 & 1984 & 2001 & 2019 \\
\hline & \multicolumn{3}{|c|}{ Bare land } & \multicolumn{3}{|c|}{ Built-up area } & \multicolumn{3}{|c|}{ Mixed forest } & \multicolumn{3}{|c|}{ Wetland forest } \\
\hline & \multicolumn{12}{|c|}{ Area $\left[\mathrm{km}^{2}\right]$} \\
\hline Alimosho & 16.84 & 28.48 & 0.32 & 4.10 & 91.26 & 150.88 & 118.83 & 44.87 & 10.53 & 43.82 & 18.95 & 21.63 \\
\hline Badagry & 26.11 & 40.37 & 17.98 & 0.83 & 16.43 & 111.63 & 188.05 & 207.05 & 130.91 & 110.65 & 123.78 & 130.28 \\
\hline Eti-Osa & 6.85 & 24.52 & 15.35 & 9.06 & 35.63 & 113.89 & 86.20 & 79.24 & 35.00 & 58.37 & 24.78 & 12.66 \\
\hline Ifako-Ijaiye & 6.78 & 4.44 & 0.00 & 3.21 & 18.12 & 25.21 & 15.35 & 3.57 & 1.00 & 1.05 & 0.26 & 0.31 \\
\hline Ikorodu & 3.91 & 13.61 & 1.45 & 2.27 & 42.06 & 181.42 & 280.92 & 238.15 & 91.85 & 77.06 & 69.34 & 88.94 \\
\hline Ojo & 16.24 & 16.92 & 5.75 & 1.21 & 36.34 & 62.00 & 54.17 & 42.18 & 22.93 & 41.98 & 47.75 & 54.37 \\
\hline
\end{tabular}

LGA - Local Government Areas.

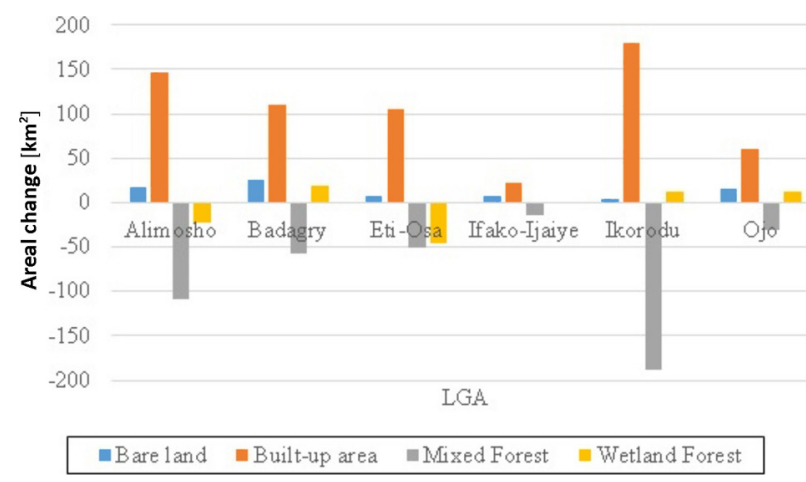

Fig. 4. Areal changes in the coverage of land cover within the six focus LGAs during 1984-2019.

vegetation, wetlands and green spaces. As observed in Figure 2, the origination of the urban expansion was from the centre of the metropolis outwards.

Table 2 presents the areal changes in land cover within the six focus LGAs, during 1984-2019. With the exception of Eti-Osa LGA, all the LGAs experienced a diminution in bare lands. The highest losses of bare land occurred in Alimosho LGA $\left(-16.52 \mathrm{~km}^{2}\right)$ and Ojo LGA $\left(-10.49 \mathrm{~km}^{2}\right)$. There was an expansion of built-up areas in all the LGAs, with the highest increases observed in Alimosho LGA $\left(+146.78 \mathrm{~km}^{2}\right)$ and Ikorodu LGA $\left(+179.15 \mathrm{~km}^{2}\right)$. The depletion in mixed forests and wetlands was consistent with the general trend presented in Table 1. The highest losses of mixed forests occurred in Alimosho LGA $\left(-108.30 \mathrm{~km}^{2}\right)$ and Ikorodu LGA $\left(-189.07 \mathrm{~km}^{2}\right)$, while the highest losses of wetland forests occurred in Alimosho LGA $\left(-22.19 \mathrm{~km}^{2}\right)$ and Eti-Osa LGA $\left(-45.71 \mathrm{~km}^{2}\right)$. Figure 4 shows the areal changes in the coverage of land cover within the six focus LGAs during 1984-2019.

Figure 5 shows the spatial variation of LST for the same periods. There is a general trend of increasing surface temperatures during 1984-2019.
Table 3. Minimum and maximum LSTs $\left[{ }^{\circ} \mathrm{C}\right]$ associated with the different land cover classes.

\begin{tabular}{|c|l|r|c|c|}
\hline Year & \multicolumn{1}{|c|}{ Land Cover } & ${ }^{*} \mathrm{~N}$ & Min LST & Max LST \\
\hline 1984 & Bare Land & 43 & 25.56 & 31.32 \\
\cline { 2 - 5 } & Built-up Area & 620 & 23.75 & 32.86 \\
\cline { 2 - 5 } & Mixed Forest & 107 & 23.75 & 30.86 \\
\cline { 2 - 5 } & Wetland Forest & 42 & 25.28 & 29.56 \\
\cline { 2 - 5 } & Total & 816 & 23.75 & 32.86 \\
\hline 2001 & Bare Land & 43 & 25.60 & 33.38 \\
\cline { 2 - 5 } & Built-up Area & 620 & 25.57 & 34.26 \\
\cline { 2 - 5 } & Mixed Forest & 107 & 24.91 & 31.87 \\
\cline { 2 - 5 } & Wetland Forest & 42 & 25.00 & 31.14 \\
\cline { 2 - 5 } & Total & 816 & 24.91 & 34.26 \\
\hline \multirow{1}{*}{2019} & Bare Land & 30 & 27.88 & 32.34 \\
\cline { 2 - 5 } & Built-up Area & 411 & 26.24 & 33.83 \\
\cline { 2 - 5 } & Mixed Forest & 94 & 25.74 & 33.17 \\
\cline { 2 - 5 } & Wetland Forest & 42 & 22.73 & 33.12 \\
\cline { 2 - 5 } & Total & 577 & 22.73 & 33.83 \\
\hline
\end{tabular}

${ }^{*} \mathrm{~N}$ - no. of community sample points.

LST - land surface temperature.

Table 3 shows the minimum and maximum LSTs which are associated with the different land cover classes. In 1984, the minimum and maximum temperatures of $27.37^{\circ} \mathrm{C}$ and $31.95^{\circ} \mathrm{C}$ were observed in Eti-Osa and Ajeromi-Ifelodun LGAs, respectively. In 2001, the minimum and maximum temperatures of $28.19^{\circ} \mathrm{C}$ and $31.56^{\circ} \mathrm{C}$ were observed at Epe and Agege LGAs, respectively. In 2019, the minimum and maximum temperatures of $29.01^{\circ} \mathrm{C}$ and $32.84^{\circ} \mathrm{C}$ were observed at Badagry and Agege LGAs, respectively. During 1984-2019, the highest temperature changes were observed in the following LGAs: EtiOsa $\left(+4.10^{\circ} \mathrm{C}\right)$, Alimosho $\left(+3.41^{\circ} \mathrm{C}\right)$, Ifako-Ijaiye $\left(+3.25^{\circ} \mathrm{C}\right)$ and Ikorodu $\left(+3.19^{\circ} \mathrm{C}\right)$. Generally, the mean LST in Lagos State increased from $28.60^{\circ} \mathrm{C}$ in 1984 to $29.65^{\circ} \mathrm{C}$ in 2001 and finally to $30.76^{\circ} \mathrm{C}$ in 2019. The increases in mean LST across the state during $1984-2001$ and $2001-2019$ were $+1.05^{\circ} \mathrm{C}$ 


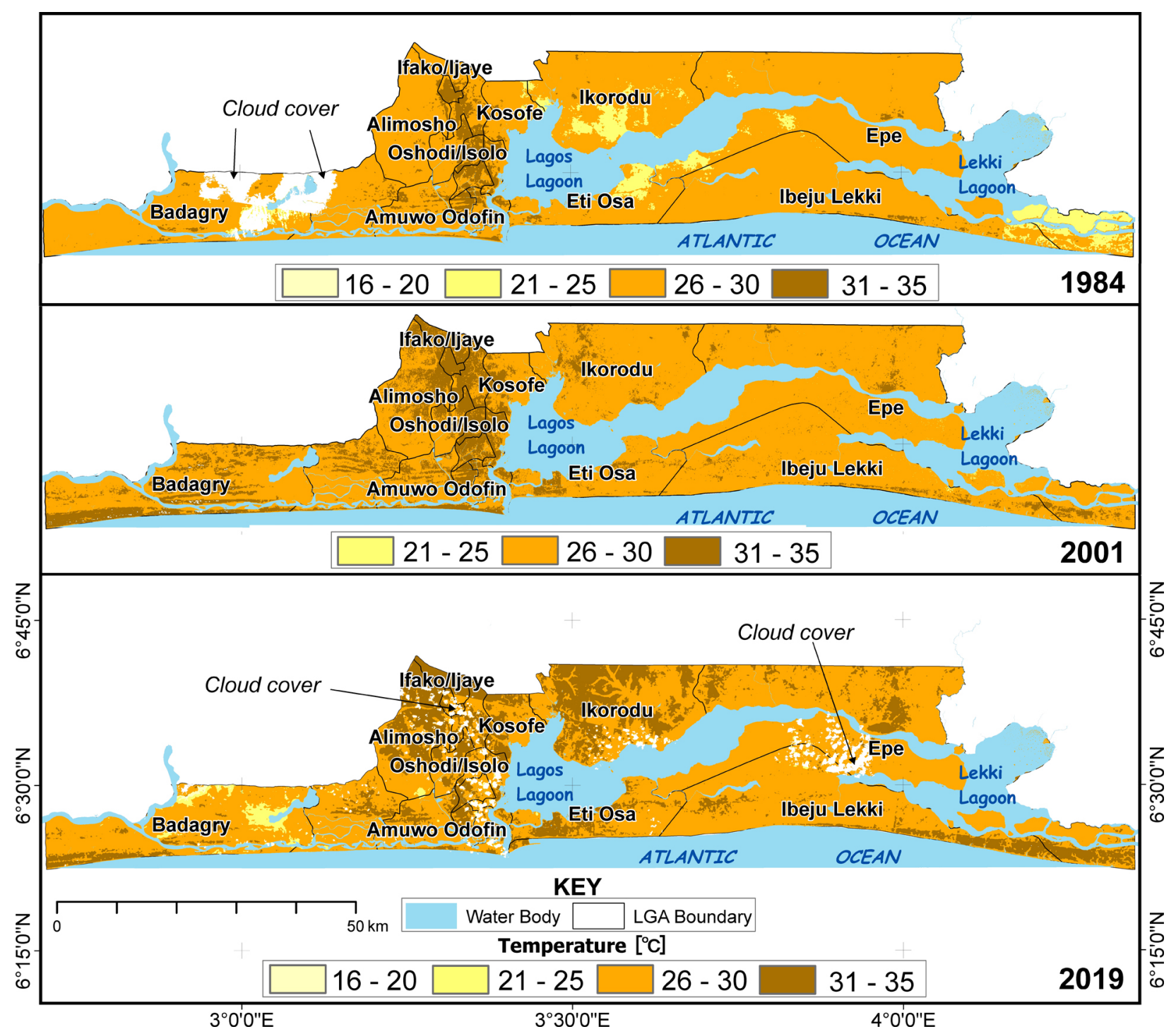

Fig. 5. Spatial variation in LST.

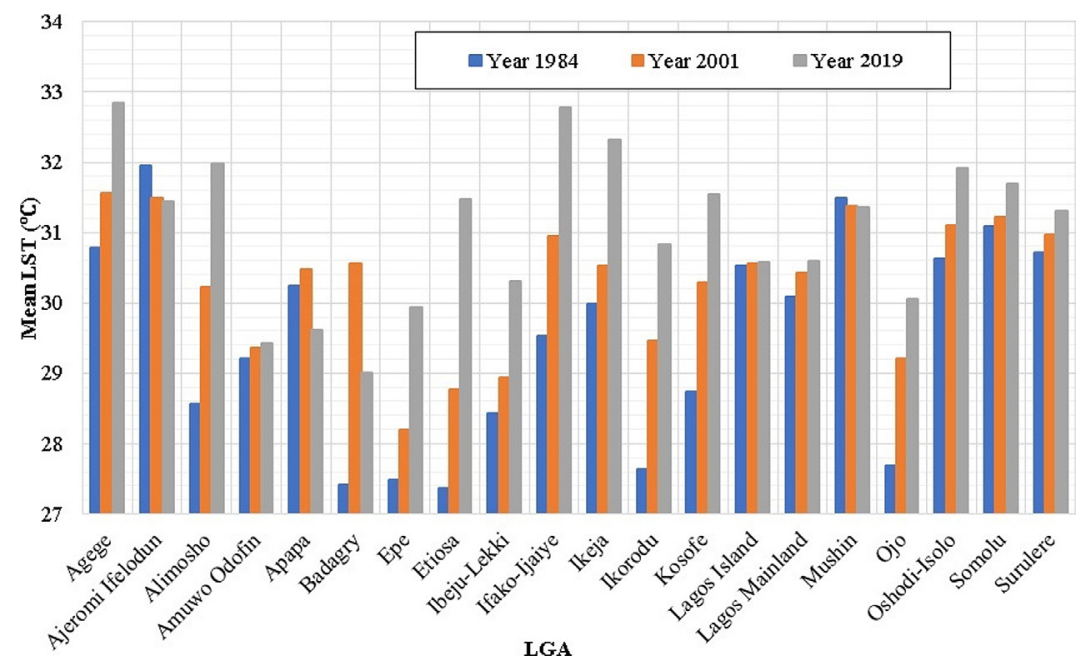

Fig. 6. Distribution of mean LST. 


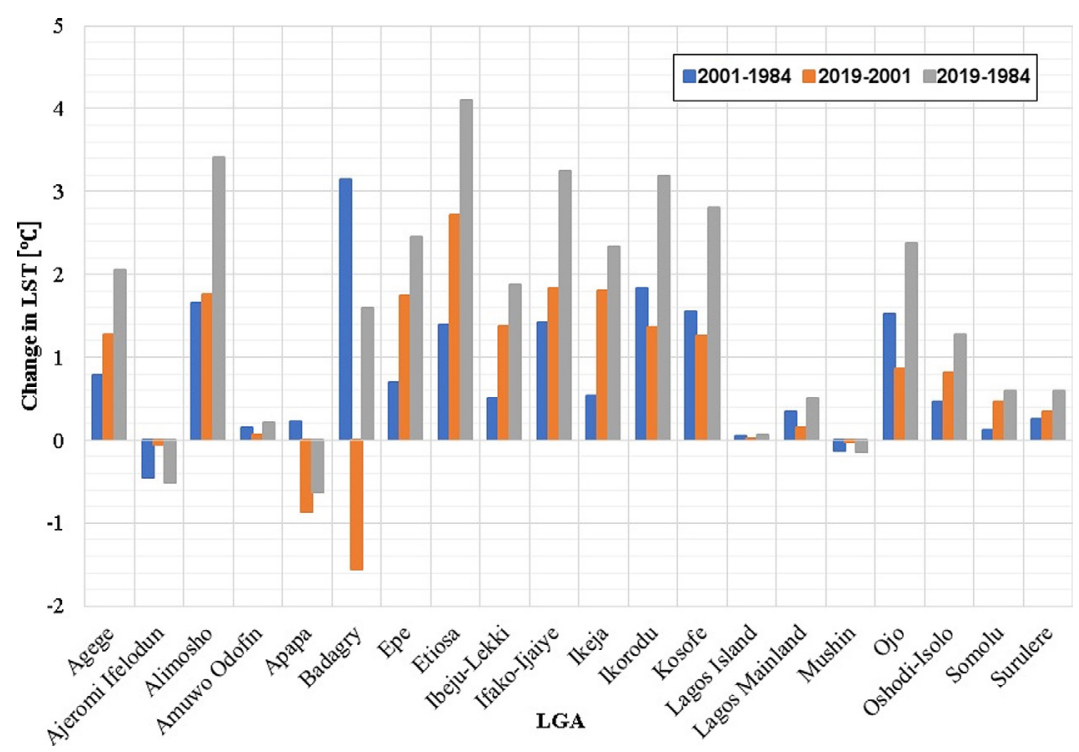

Fig. 7. Changes in mean LST.

and $+1.11^{\circ} \mathrm{C}$, respectively while the cumulative increase in the mean LST in the state during 19842019 was $2.16^{\circ} \mathrm{C}$. The distribution and changes in mean LST are illustrated graphically in Figures 6 and 7 , respectively.

\section{Relationship between land cover and LST}

The mean temperatures observed for each land cover class were as follows:

- in 1984: bare land $\left(28.43^{\circ} \mathrm{C}\right)$, built-up area $\left(28.97^{\circ} \mathrm{C}\right)$, mixed forest $\left(27.09^{\circ} \mathrm{C}\right)$ and wetland forest $\left(27.28^{\circ} \mathrm{C}\right)$,

- in 2001: bare land $\left(29.48^{\circ} \mathrm{C}\right)$, built-up area $\left(30.10^{\circ} \mathrm{C}\right)$, mixed forest $\left(27.92^{\circ} \mathrm{C}\right)$ and wetland forest $\left(27.86^{\circ} \mathrm{C}\right)$.

- in 2019: bare land $\left(31.38^{\circ} \mathrm{C}\right)$, built-up area $\left(31.14^{\circ} \mathrm{C}\right)$, mixed forest $\left(29.49^{\circ} \mathrm{C}\right)$ and wetland forest $\left(29.40^{\circ} \mathrm{C}\right)$.

Figure 8 depicts a graphical illustration of the mean LSTs associated with the different land cover classes. Some parts of Alimosho and Ikorodu LGAs are shown in Figures 9 and 10, respectively. Some of the Bus Rapid Transit (BRT) corridors within Lagos State are located in Ikorodu and
Ikotun (Global Mass Transit 2015). The burgeoning population, new settlements and dense transportation networks are urbanisation factors that contribute to increasing surface temperature in both LGAs.

The CI further links the spatial structure and temporal changes in LST - land cover intensities. Table 4 shows the CIs for the four land cover classes which are considered. We observe that built-up area or urban growth is the main contributor to increases in LST across the state. During

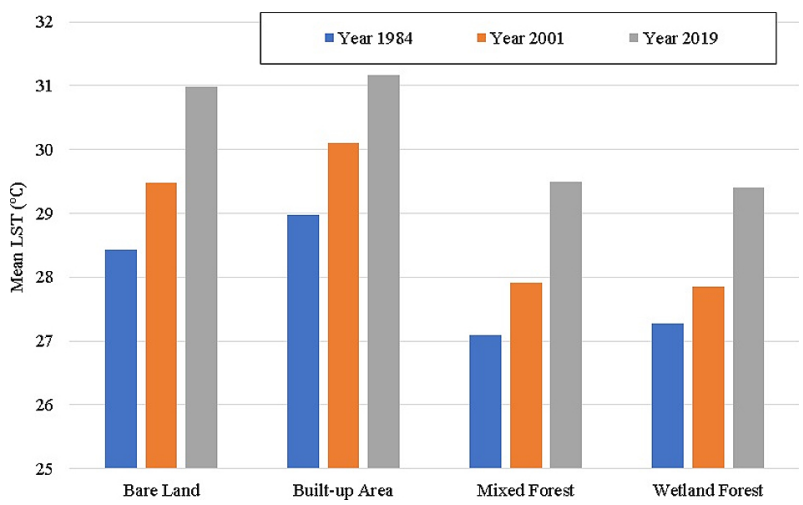

Fig. 8. Mean LSTs associated with the different land cover classes.

Table 4. Contribution index (CI) for 1984, 2001 and 2019.

\begin{tabular}{|c|c|c|c|c|c|c|c|c|c|}
\hline \multirow{2}{*}{ Land cover } & \multicolumn{3}{|c|}{1984} & \multicolumn{3}{|c|}{2001} & \multicolumn{3}{|c|}{2019} \\
\hline & $\mathrm{Dt}\left[{ }^{\circ} \mathrm{C}\right]$ & $\mathrm{S}$ & $\mathrm{CI}$ & $\mathrm{Dt}\left[{ }^{\circ} \mathrm{C}\right]$ & $S$ & $\mathrm{CI}$ & $\mathrm{Dt}\left[{ }^{\circ} \mathrm{C}\right]$ & $S$ & $\mathrm{CI}$ \\
\hline Bare land & -0.17 & 0.04 & -0.01 & -0.17 & 0.05 & -0.01 & 0.23 & 0.04 & 0.01 \\
\hline Built-up area & 0.37 & 0.04 & 0.01 & 0.45 & 0.13 & 0.06 & 0.41 & 0.28 & 0.12 \\
\hline Mixed forest & -1.51 & 0.47 & -0.71 & -1.73 & 0.40 & -0.70 & -1.27 & 0.29 & -0.37 \\
\hline Wetland forest & -1.32 & 0.22 & -0.29 & -1.79 & 0.21 & -0.38 & -1.36 & 0.18 & -0.25 \\
\hline
\end{tabular}




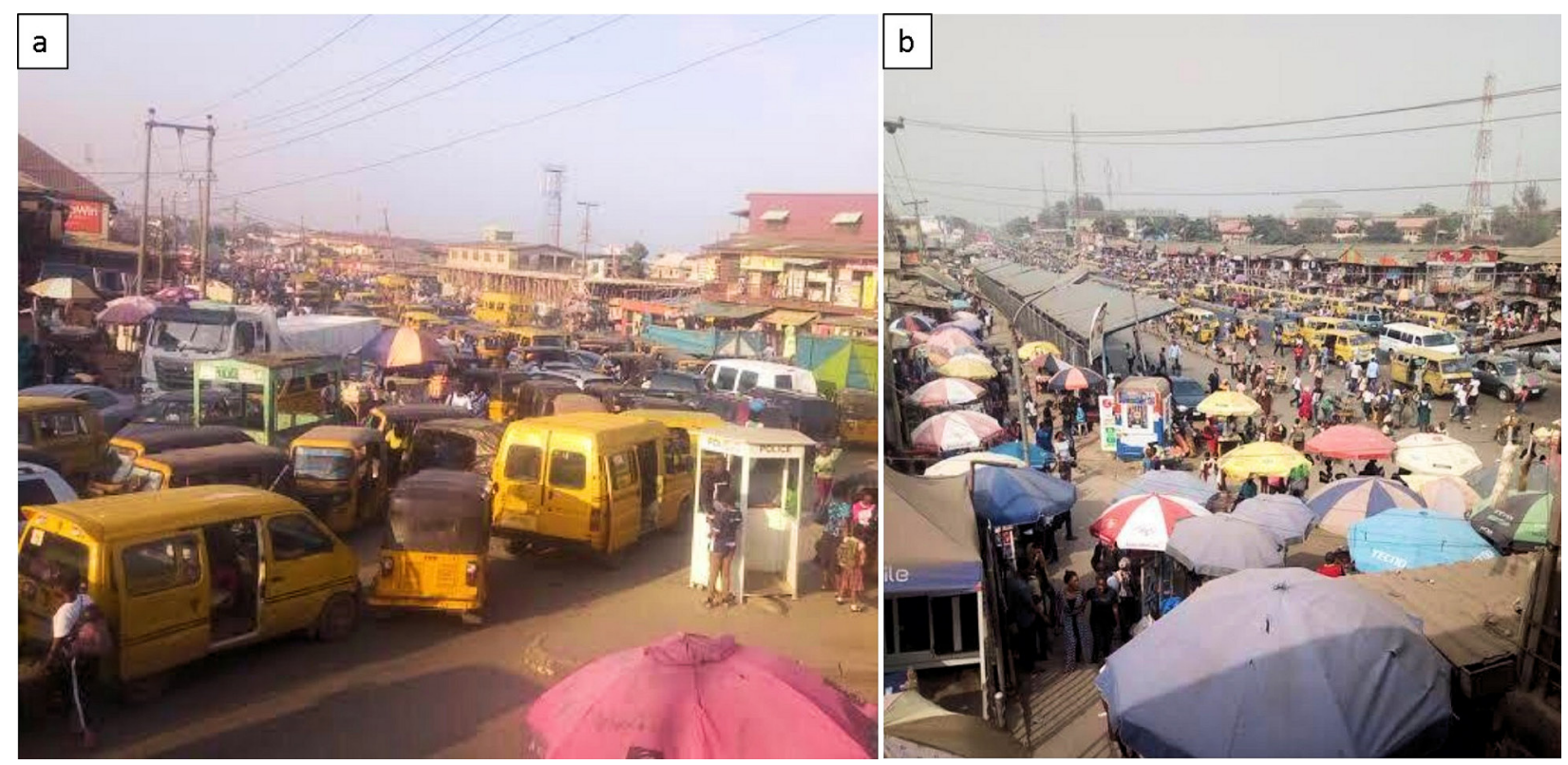

Fig. 9. Some parts of Alimosho LGA. a - Ikotun Bus stop/garage; b - Bus Rapid Transit (BRT) terminal along Ikotun-Idimu road in Alimosho LGA (year 2020).

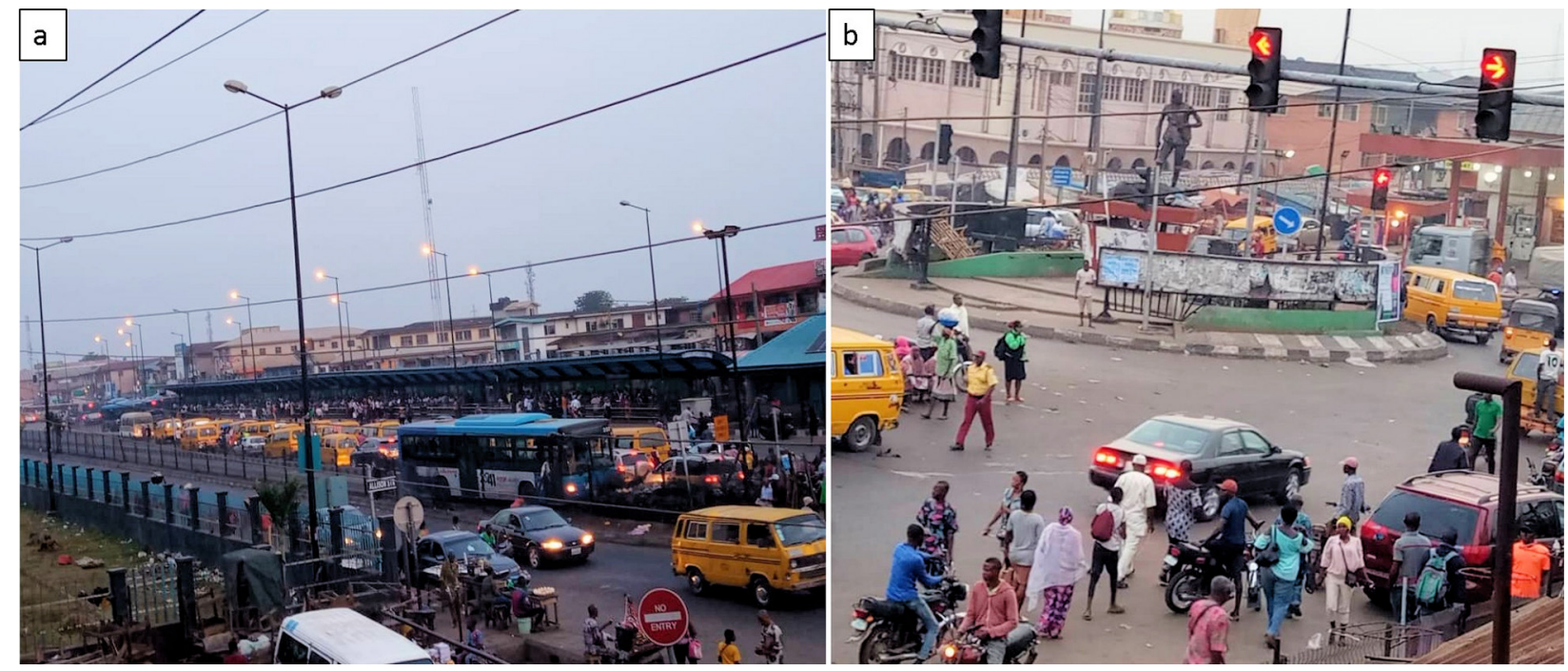

Fig. 10. Some parts of Ikorodu LGA. a - Sprawl in Ikorodu driven partly by the construction of dual-carriage main access; b - Ikorodu Bus stop/garage (year 2020).

1984-2019, its contribution remained positive, while being aided slightly in 2019 by bare land. Conversely, the heat mitigation parameter for mixed and wetland forests shows negative values during 1984-2019, although the values for mixed forests declined sharply in the latter year while those for wetland forests remained relatively stable. The decline in the values of mixed forests is, ostensibly, tied to the reduction in the quantum of these ecological assets as a consequence of urban growth.

\section{Potential influence of changing LST on urban outdoor thermal comfort}

Further to establishing the warming surface temperature of the metropolis and state, it becomes imperative to explore its potential influence on outdoor thermal comfort. This requirement arises consequent to the need for lessons to facilitate urban design, landscape and open space planning and design and urban green infrastructure provision in the state. As noted in 


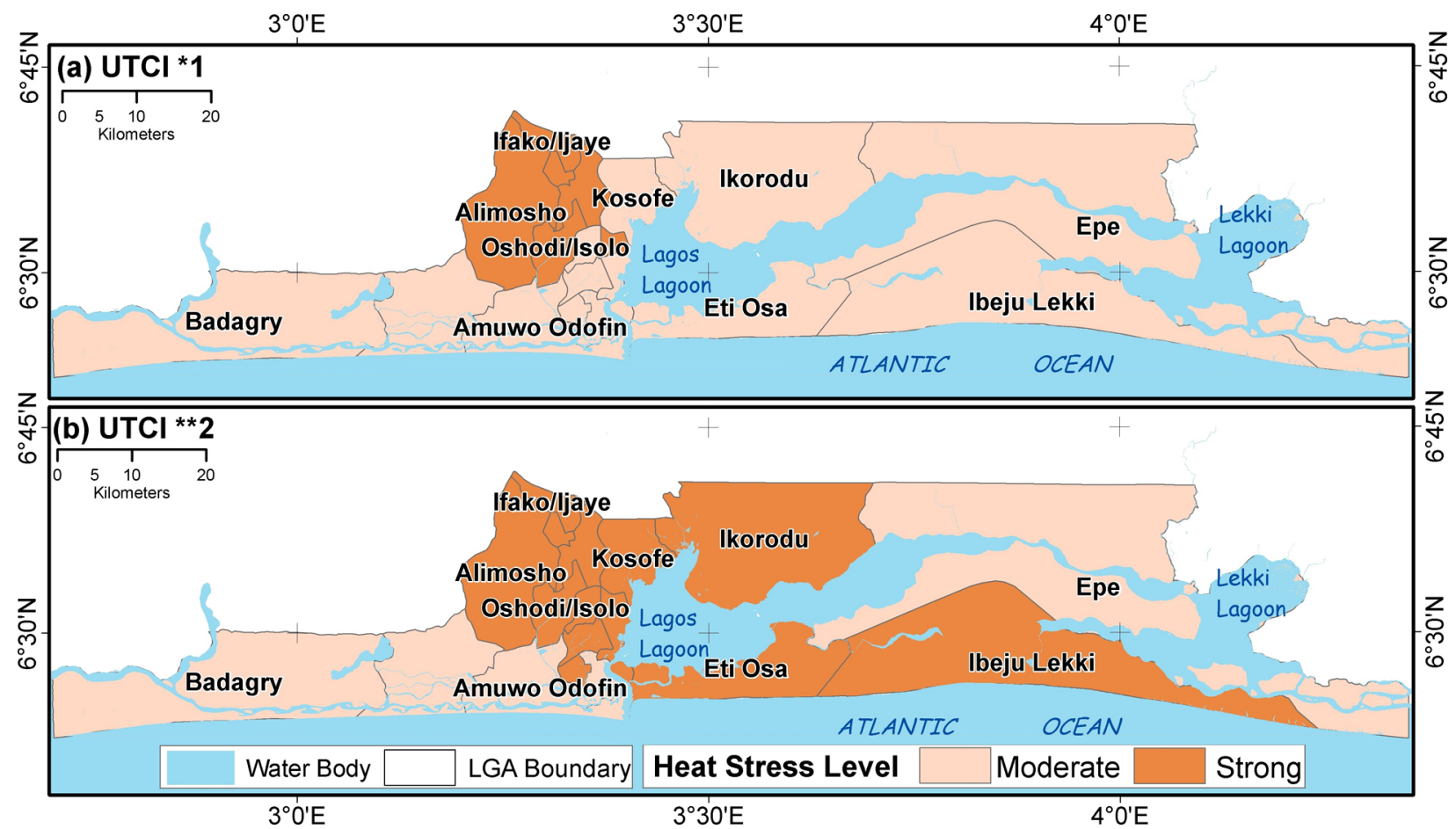

Fig. 11. Heat stress map for Lagos State on 30 January 2019 with mean LST. a - UTCI *1 from utci.org; b - UTCI **2 from climatechip.org.

Table 5. UTCI heat stress index with LST for Lagos State on January 30, 2019.

\begin{tabular}{|c|c|c|c|c|c|c|}
\hline $\mathrm{S} / \mathrm{N}$ & LGA & $\begin{array}{c}\text { Mean LST }\left[{ }^{\circ} \mathrm{C}\right] \\
2019\end{array}$ & $\begin{array}{c}\text { UTCI }{ }^{*} 1 \\
{\left[{ }^{\circ} \mathrm{C}\right]}\end{array}$ & $\begin{array}{c}\text { Heat Stress } \\
\text { Level }{ }^{*} 1\end{array}$ & $\begin{array}{c}\text { UTCI **2 } \\
{\left[{ }^{\circ} \mathrm{C}\right]}\end{array}$ & $\begin{array}{c}\text { Heat Stress } \\
\text { Level } * 2\end{array}$ \\
\hline 1 & Agege & 32.84 & 33.83 & $\mathrm{~S}$ & 35.58 & $\mathrm{~S}$ \\
\hline 2 & Ajeromi-Ifelodun & 31.44 & 31.70 & $\mathrm{M}$ & 33.62 & $\mathrm{~S}$ \\
\hline 3 & Alimosho & 31.98 & 32.50 & $\mathrm{~S}$ & 34.36 & $\mathrm{~S}$ \\
\hline 4 & Amuwo-Odofin & 29.42 & 28.80 & $\mathrm{M}$ & 30.98 & $\mathrm{M}$ \\
\hline 5 & Apapa & 29.61 & 29.10 & $\mathrm{M}$ & 31.22 & $\mathrm{M}$ \\
\hline 6 & Badagry & 29.01 & 28.30 & $\mathrm{M}$ & 31.46 & $\mathrm{M}$ \\
\hline 7 & Epe & 29.94 & 29.60 & $\mathrm{M}$ & 30.61 & $\mathrm{M}$ \\
\hline 8 & Eti-Osa & 31.47 & 31.80 & $\mathrm{M}$ & 33.66 & $\mathrm{~S}$ \\
\hline 9 & Ibeju-Lekki & 30.30 & 30.10 & $\mathrm{M}$ & 32.11 & $\mathrm{~S}$ \\
\hline 10 & Ifako-Ijaiye & 32.78 & 33.70 & $\mathrm{~S}$ & 35.49 & $\mathrm{~S}$ \\
\hline 11 & Ikeja & 32.32 & 33.00 & $\mathrm{~S}$ & 34.84 & $\mathrm{~S}$ \\
\hline 12 & Ikorodu & 30.83 & 30.10 & $\mathrm{M}$ & 32.10 & $\mathrm{~S}$ \\
\hline 13 & Kosofe & 31.55 & 31.90 & $\mathrm{M}$ & 33.77 & $\mathrm{~S}$ \\
\hline 14 & Lagos Island & 30.58 & 30.50 & $\mathrm{M}$ & 32.48 & $\mathrm{~S}$ \\
\hline 15 & Lagos Mainland & 30.59 & 30.50 & $\mathrm{M}$ & 32.49 & $\mathrm{~S}$ \\
\hline 16 & Mushin & 31.36 & 31.60 & $\mathrm{M}$ & 33.51 & $\mathrm{~S}$ \\
\hline 17 & Ojo & 30.06 & 29.70 & $\mathrm{M}$ & 31.80 & $\mathrm{M}$ \\
\hline 18 & Oshodi-Isolo & 31.91 & 32.40 & $\mathrm{~S}$ & 34.26 & $\mathrm{~S}$ \\
\hline 19 & Somolu & 31.69 & 32.10 & $\mathrm{~S}$ & 33.96 & $\mathrm{~S}$ \\
\hline 20 & Surulere & 31.31 & 31.20 & $\mathrm{M}$ & 33.10 & $\mathrm{~S}$ \\
\hline & Maximum temp for that day & 34.00 & 35.70 & $\mathrm{~S}$ & 37.30 & $\mathrm{~S}$ \\
\hline
\end{tabular}

UTCI * 1 from utci.org with mean LST 2019 , relative humidity $65 \%$ and wind speed of $3.33 \mathrm{~m} / \mathrm{s}$.

UTCI **2 from climatechip.org with mean LST 2019 and relative humidity $65 \% . S=$ strong heat stress; M = moderate heat stress outdoors.

LGA - Local Government Areas; LST - land surface temperature; M - moderate heat stress outdoors; RH - relative humidity; S - strong heat stress outdoors; UTCI - Universal Thermal Climate Index. 
the literature, this need arises because research has grappled with the concept of outdoor thermal comfort along with the climatic variables to understand the influencing factors that can be applied in urban design (Rizwan et al. 2008, Honjo 2009, Achour-Younsi, Kharrat 2016). A background to this need hinges on the sensitivity of humans and their activities to weather conditions and environmental heat, since high temperatures may result in heat stress to the body, along with impaired public health and well-being (Orosa et al. 2014, Walls et al. 2015, Zare et al. 2018).

Relying on these studies, therefore, the mean LST values for January 2019 which were derived for Lagos State were used as a proxy to represent air temperature for calculating the thermal indices at those locations at about 11:00 AM Nigerian time, which was the image acquisition time on 30 January 2019. This is particularly compelling, since the state has only one weather station and available data from the Lagos State historical weather almanac (WWO 2020) shows that the maximum temperature for Lagos/Ikeja station on that date (which was measured between 3:00-4:00 PM Nigerian time) was $34^{\circ} \mathrm{C}$ with a low of $28^{\circ} \mathrm{C}$ and a $\mathrm{RH}$ of $65 \%$. Using the derived LST values for the state and combining them with the meteorological data from the historical weather almanac (WWO 2020), the UTCI outdoor thermal sensation index for Lagos State on 30 January 2019 was calculated online (Climate CHIP 2020), as shown in Table 5. While utci.org (UTCI ${ }^{*} 1$ ) requires the input of three parameters of air temperature, $\mathrm{RH}$ or vapour pressure and wind speed, Climate CHIP (UTCI ${ }^{*} 2$ ) requires only two inputs of air temperature and either dew point temperature or $\mathrm{RH}$ or vapour pressure with an inherent wind speed of 1 $\mathrm{m} \times \mathrm{s}^{-1}$ and no direct sunlight outdoors. Figure 11 shows the heat stress maps of the state, as calculated with these two online sites. Based on the derived UTCIs, the LGAs were classified into either strong or moderate heat stress level. Six LGAs (Agege, Ifako-Ijaiye, Ikeja, Alimosho, Oshodi-Isolo and Somolu) recorded the highest heat stress levels in both UTCI ${ }^{*} 1$ and UTCI ${ }^{*} 2$. Generally, higher temperatures are felt in LGAs within the metropolis and this manifested in the derived heat stress levels.

\section{Discussion}

We observe that the main driver of land cover change is built-up area or urban development which had grown by over $770 \%$ of the area covered in 1984. The reduction of the mixed forests and wetlands by $665 \mathrm{~km}^{2}$ and about $116 \mathrm{~km}^{2}$, respectively, is a further confirmation that urban growth has displaced areas which contain ecological assets. The slight decline in the area of water bodies is probably the result of various reclamation projects in the state which commenced in 1984, including the Majidun Foreshore and Banana Island projects.

Further analysis of land cover changes in LGAs (Table 2) shows five LGAs as the focal points of expansion of urban growth together with their corresponding areas of decline in ecological assets. Ikorodu LGA had the highest growth with over $179 \mathrm{~km}^{2}$ of built-up areas and a phenomenal loss in mixed forests by $189 \mathrm{~km}^{2}$ during 1984-2019. In the same period, this was closely followed by Alimosho LGA, with an increase of about $146 \mathrm{~km}^{2}$ in built-up areas and a decimation of mixed forests by $108 \mathrm{~km}^{2}$, with only $10 \mathrm{~km}^{2}$ left in 2019. Surprisingly, Badagry LGA in the west is the third highest area of urban growth with about $110 \mathrm{~km}^{2}$ increase in built-up areas during 1984-2019. However, it was still left with an appreciable store of mixed forests and wetland forests in 2019. The growth in built-up areas in these hitherto rural LGAs attests to the fact of occurrence of rapid urban growth in hitherto far-flung rural areas which are associated with lower land costs. Eti-Osa LGA in the south, which is home to the rich, has the fourth highest expanse of built-up areas. The desire by the nouveau riche to be in this area is undoubtedly among the drivers of its growth.

From 1984, the shape and locations of the high LST range of $31-35^{\circ} \mathrm{C}$ mirrors the form and spread eastwards, northwards and westwards of built-up areas during 2001-2019. For instance, in 1984, Alimosho and Ikorodu LGAs, with built-up areas of $4.10 \mathrm{~km}^{2}$ and $2.27 \mathrm{~km}^{2}$, respectively, experienced mean LSTs of $28.6^{\circ} \mathrm{C}$ and $27.6^{\circ} \mathrm{C}$, while the mean LST then was $28.6^{\circ} \mathrm{C}$. This indicated a moderating influence of ecological assets since these LGAs were principally rural at the time. By 2019, when the built-up areas of the two LGAs 
had expanded phenomenally to $150.88 \mathrm{~km}^{2}$ and $181.42 \mathrm{~km}^{2}$, respectively, their mean LSTs correspondingly increased to $32.0^{\circ} \mathrm{C}$ and $30.8^{\circ} \mathrm{C}$. At the same time, the rural and highly forested Badagry LGA in the west, which also experienced high growth in built-up area from 0.83 $\mathrm{km}^{2}$ in 1984 to $111.63 \mathrm{~km}^{2}$ in 2019, maintained a mean LST of $29.0^{\circ} \mathrm{C}$ in 2019 . This mean LST value indicated a continuing moderating influence of mixed forests, which were available to the extent of $130.91 \mathrm{~km}^{2}$ in 2019 . This mean LST value for Badagry aligns somewhat with the earlier findings by Ojeh et al. (2016), which observed $T_{\text {mean }}$ to be $27.5^{\circ} \mathrm{C}$ in December in the synoptic observation of seasonal variation and intensity of UHI and air temperature over urban and rural Lagos State during 2014-2015. Lower surface temperatures in 2019 generally characterise the distant and still rural LGAs of Badagry and Epe. Apapa LGA with its port complex, which was previously a major industrial manufacturing base, is in this LST segment perhaps due to the recent decline in manufacturing, since many manufacturing concerns have either closed or relocated to neighbouring countries.

The heat stress levels from utci.org are lower perhaps due to the fact that the actual wind

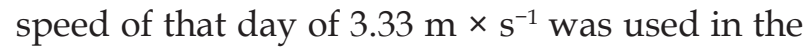
calculation, while a wind speed of $1 \mathrm{~m}^{\times} \mathrm{s}^{-1}$ was embedded in the heat stress levels from climatechip.org. The higher wind speed expectedly induces more evaporative cooling and hence lower temperatures. In consequence, only seven LGAs from utci.org show strong heat stress, while only five LGAs from climatechip.org display moderate heat stress. Significantly developing rural LGAs such as Badagry and Epe, which have reasonable remaining amounts of areas of mixed forests, show moderate heat stress levels, while the rapidly built-up Alimosho LGA shows strong heat stress levels on both UTCI ${ }^{*} 1$ and UTCI ${ }^{* *} 2$.

In a related study, Wang et al. (2020) conducted city-scale UTCI mapping during periods of heat waves in the Yangtze River Delta urban agglomeration in China, using satellite data. Their findings showed that the UTCI was generally higher in urban areas and varied considerably with land cover types. The changing patterns of thermal comfort under the influence of urbanisation was also shown in the work of $\mathrm{Fu}$ et al.
(2019), which dealt with the dynamics of urban thermal comfort in the four major capital cities of China. Their work showed that urbanisation could increase urban temperature and decrease the RH and the wind velocity. According to Yahia et al. (2018), dense trees could enhance thermal comfort conditions. This finding of Yahia et al. might explain the moderate heat stress levels and lower temperatures observed at the fringes of Lagos State in Epe and Badagry LGAs, where vegetation cover is more widespread. Other researchers have also confirmed the general trend of less comfortable temperatures within urban centres in African cities such as Abuja (Isioye et al. 2020) and Nairobi (Ongoma et al. 2016) and in 173 other African cities (Rohat et al. 2019).

These results indicate the potential discomfort levels which people in various LGAs of the state undergo as a result of excessive outdoor heat, as gauged by LST. The heat stress levels shown are signals to the potential influence of LST and UHI on urban outdoor thermal comfort in various parts of the state.

\section{Conclusions}

The study has monitored the changing land cover, LST and thus UHI in Lagos State during 1984-2019 through the use of spatio-temporal Landsat data. While the study established the fact of rapid and continuing urban expansion into hitherto rural areas along with continuing warming of the state, it indicated a strong link between high LST intensities and rapid urban growth in some LGAs. The UTCI heat stress index derived for the state with LST results points to a potential influence of LST and thus UHI on the outdoor thermal comfort in the state. Generally, there is lower thermal comfort arising from higher temperatures and consequent heat stress within the metropolitan areas of the state. The results further reinforce the need for policies and actions to rein in urban sprawl and to improve the thermal quality of outdoor spaces through increased urban tree canopy and green infrastructure. A few areas for further research manifest from this study. A further investigation of LST to coincide with the period of maximum daily temperature, which usually peaks between 3:00-4:00 PM local 
time, is needed in the dry season to ascertain how closely it mirrors air temperature. Landsat overpass time, which usually occurs in the morning, neither coincides with the time of maximum temperature nor does it lend to a night-time assessment of LST. A further use of vegetation indices is desirable to underscore the LST-land cover relationship as well as the UHI urban-rural continuum in the state.

Field measurements of meteorological data in rapidly developed LGAs such as Alimosho and Ikorodu are imperative to generate data with which to test and validate the outdoor thermal indices in the state, provided funding can ever be found. In addition, the modelling of selected open spaces/pockets of vegetated spaces in the highly built-up LGAs such as Alimosho, Agege, Ikeja and Surulere, with ENVI-MET software, for the contribution of green infrastructure to LST modulation and outdoor thermal comfort, is necessary to generate indices for urban green space/landscape planning and design. The existence of only one weather station to date in the entire state presented a limitation to any attempt to compare the derived LST to the actual surface or air temperature, especially for the developing rural LGAs.

Finally, conscious that LST is used here as a proxy for air temperature due to lack of statewide temperature data, it is safe to emphasise that findings on outdoor heat stress remain possibilities which need further studies of in-situ measurements for affirmation.

\section{Conflict of interest disclosure}

The authors declare that no conflicts of interest exist.

\section{Funding}

This research did not receive any specific grant from funding agencies in the public, commercial, or not-for-profit sectors.

\section{Acknowledgements}

The authors are grateful to the United States Geological Survey (USGS) for access to the Landsat imageries used for the study, the Universal Thermal Climate Index (UTCI) development team for provision of the UTCI interactive calculator, and the Climate Change Heat Impact and Prevention (Climate CHIP) team for provision of the WetBulb Globe Temperature (WBGT) heat stress calculator. The assistance of $\mathrm{Mr}$. Ahmed Ishola Moshood and Mr. Tochi Praise Nwaoru in the acquisition of field pictures is acknowledged. We are very grateful to the editor and reviewers for their painstaking multiple reviews freely given.

\section{Author Contributions}

Conceptualisation and design: JNO, CJO, PCN; Acquisition of data: JNO, CJO, OED; Data analysis and interpretation: JNO, CJO, PCN, OED, LCI; Manuscript writing and revision: JNO, CJO, OED, LCI.

\section{References}

Achour-Younsi S., Kharrat F., 2016. Outdoor thermal comfort: Impact of the geometry of an urban street canyon in the Mediterranean subtropical climate - Case study Tunis, Tunisia. Proceedia - Social and Behavioral Sciences 216: 689-700. DOI 10.1016/j.sbspro.2015.12.062.

Alademomi A.S., Okolie C.J., Daramola O.E., Agboola R.O., Salami T.J., 2020. Assessing the relationship of LST, NDVI and EVI with land cover changes in the Lagos Lagoon environment. Quaestiones Geographicae 39(3): 87-109. DOI 10.2478/quageo-2020-0025.

Błażejczyk K., Jendritzky G., Bröde P., Fiala D., Havenith G., Epstein Y., Psikuta A., Kampmann B., 2013. An introduction to the Universal Thermal Climate Index. Geographia Polonica 86(1): 5-10. DOI 10.7163/GPol.2013.1.

Błażejczyk, K., Epstein Y., Jendritzky G., Staiger H., Tinz B., 2012. Comparison of UTCI to selected thermal indices. International Journal of Biometeorology 56: 515-535. DOI 10.1007/s00484-011-0453-2.

Bröde P., 2020. UTCI Universal Thermal Climate Index. Online: utci.org/ (accessed 12 March 2020).

Chadchan J., Shankar R., 2009. Emerging urban development issues in the context of globalization. Journal of ITPI (Institute of Town Planners, India) 6(2): 78-85.

Chen F., Liu Y., Liu Q., Qin F., 2015. A statistical method based on remote sensing for the estimation of air temperature in China. International Journal of Climatology 35(8): 2131-2143. DOI 10.1002/joc.4113.

Cheng V., Ng E., 2006. Thermal comfort in urban open spaces for Hong Kong. Architectural Science Review 49: 236-242.

Choi S., Jin D., Seong N., Jung D., Han K., 2020. Correlation of air temperature and land surface temperature of Landsat-8 in cities of South Korea. EGU General Assembly 2020. DOI 10.5194/egusphere-egu2020-13886 (accessed: 18 January 2021).

Climate CHIP, 2020. Climate change heat impact \& prevention. Online: climatechip.org/ (accessed 3 December 2020).

Cui L., Shi J., 2012. Urbanization and its environmental effects in Shanghai, China. Urban Climate 2: 1-15. DOI 10.1016/j.uclim.2012.10.008. 
De Sherbinin A., Schiller A., Pulsipher A., 2007. The vulnerability of global cities to climate hazards. Environment and Urbanisation 19: 39-64. DOI 10.1177/0956247807076725.

Deng Y., Shijie W., Xiaoyong B., Yichao T., Luhua W., Jianyong X., Fei, C., Qinghuan Q., 2018. Relationship among land surface temperature and LUCC, NDVI in typical karst area. Scientific Reports 8: 641. 12p. DOI 10.1038/ s41598-017-19088-x.

Dewan A.M., Corner R.J., 2012. The impact of land use and land cover changes on land surface temperature in a rapidly urbanizing megacity. IGARSS 2012. 6337-6339.

Ferrelli F., Bustos M., Huamantinco-Cisneros M., Piccolo M., 2015. Utilization of satellite images to study the thermal distribution in different soil covers in Bahia Blanca city (Argentina). Revista de Teledetección 4: 31-42.

Fiala D., Havenith G., Bröde P., Kampmann B., Jendritzky G., 2012. UTCI Fiala multi-node model of human heat transfer and temperature regulation. International Journal of Biometeorology 56(3): 429-441. DOI 10.1007/s00484-011-0424-7.

Fu Y., Ren Z., Yu Q., He X., Xiao L., Wang Q., Liu C., 2019. Long-term dynamics of urban thermal comfort in China's four major capital cities across different climate zones. PeerJ 7: e8026. DOI 10.7717/ peerj.8026.

Global Mass Transit 2015. Project update - Lagos bus rapid transit (BRT) system, Nigeria. Online: https://www. globalmasstransit.net/archive.php?id=18222 (accessed 19 December 2020).

Gómez J., Naranjo M., Lousada S., Velarde J.G., Castanho R.A., Loures L., 2020. Land-use changes in the canary archipelago using the CORINE data: A retrospective analysis. Land 2020. 9: 232. DOI 10.3390/land9070232i.

Good E.J., Ghent D.J., Bulgin C.E., Remedios J.J., 2017. A spatiotemporal analysis of the relationship between near-surface air temperature and satellite land surface temperatures using 17 years of data from the ATSR series. Journal of Geophysical Research: Atmospheres 122: 9185-9210. DOI 10.1002/2017JD026880.

Good E., 2015. Daily minimum and maximum surface air temperatures from geostationary satellite data. Journal of Geophysical Research: Atmospheres 120: 2306-2324. DOI 10.1002/2014JD022438.

Goshayeshi D., Shahidan M.F., Khafi F., Ehtesham E., 2013. A review of researches about human thermal comfort in semi-outdoor spaces. European Online Journal of Natural and Social Sciences 2: 516-523.

Guha S., Govil H., Dey A., Gill N., 2020. A case study on the relationship between land surface temperature and land surface indices in Raipur City, India. Geografisk Tidsskrift-Danish Journal of Geography 120(1): 35-50. DOI 10.1080/00167223.2020.1752272.

Gutman G., Huang C., Chander G., Noojipady P., Masek J.G., 2013. Assessment of the NASA-USGS global land survey (GLS) datasets. Remote Sensing of Environment 134: 249-265.

Hahs A.K., McDonnell M.J., McCarthy M.A., Vesk P.A., Corlett R.T., Norton B.A., Clemants S.E., Duncan R.P., Thompson K., Schwartz M.W., Williams N.S.G., 2009. A global synthesis of plant extinction rates in urban areas. Ecology Letters 12: 1165-1173. DOI 10.1111/j.14610248.2009.01372.x.

Hamoodi M.N., Corner R., Dewan A., 2019. Thermophysical behaviour of LULC surfaces and their effect on the urban thermal environment. Journal of Spatial Science 64(1): 111-130. DOI 10.1080/14498596.2017.1386598.

Harris Geospatial., 2020. Parallelepiped. Online: harrisgeospatial.com/docs/Parallelepiped.html (accessed 2 September 2020).
Honjo T., 2009. Thermal comfort in outdoor environment. Global Environment Research 13: 43-47.

Hou G.L., Zhang H.Y., Wang Y.Q., Qiao Z.H., Zhang, Z.X., 2010. Retrieval and spatial distribution of land surface temperature in the middle part of Jilin Province based on MODIS data. Scientia Geographica Sinica 30: 421-427.

Ibe A.C., 1988. Coastline Erosion in Nigeria. Ibadan University Press. 217p.

Isioye O.A., Ikwueze H.U. Akomolafe E.A., 2020. Urban heat island effects and thermal comfort in Abuja Municipal Area Council of Nigeria. FUTY Journal of the Environment 14(2): June 2020.

Jago-on K.A.B., Kaneko S., Fujukura R., Fujiwara A., Imai T., Matsumoto T., 2009. Urbanization and subsurface environmental issues: An attempt at DPSIR model application in Asian cities. Science of the total Environment 407(9): 3089-3104. DOI 10.1016/j.scitotenv.2008.08.004.

Janatian N., Sadeghi M., Sanaeinejad S.H., Bakhshian E., Farid A., Hasheminia S.M., Ghazanfari S., 2016. A statistical framework for estimating air temperature using MODIS land surface temperature data. International Journal of Climatology 37(3): 1181-1194. DOI 10.1002/joc.4766.

Jendritzky G., de Dear R., Havenith G., 2012. UTCI - Why another thermal index? International Journal of Biometeorology 56(3): 421-428. DOI 10.1007/s00484-011-0513-7.

Johansson E., Thorsson S., Emmanuel R., Krüger E., 2014. Instruments and methods in outdoor thermal comfort studies - The need for standardization. Urban Climate 10: 346-366. DOI 10.1016/j.uclim.2013.12.002.

Kim Y.H., Baik J.J., 2005. Spatial and temporal structure of urban heat island in Seoul. Journal of Applied Meteorology 44: 591-605. DOI 10.1175/JAM2226.1.

Liu J.G., Diamond J., 2005. China's environment in a globalizing world. Nature 435: 1179-1186. DOI 10.1038/4351179a.

Mushore T.D., Mutanga O., Odindi J., Dube T., 2017a. Linking major shifts in land surface temperatures to long term land use and land cover changes: A case of Harare, Zimbabwe. Urban Climate 20: 120-134. DOI 10.1016/j. uclim.2017.04.005.

Mushore T.D., Odindi J., Dube T., Mutanga O., 2017b. Outdoor thermal discomfort analysis in Harare, Zimbabwe in Southern Africa. South African Geographical Journal 2017. 18p. DOI 10.1080/03736245.2017.1339630.

Mutiibwa D., Strachan S., Albright T., 2015. Land surface temperature and surface air temperature in complex terrain. IEEE Journal of Selected Topics in Applied Earth Observations and Remote Sensing 8(10): 4761-4774. DOI 10.1109/ JSTARS.2015.2468594.

Napoli C.D., Pappenberger F., Cloke H.L., 2018. Assessing heat-related health risk in Europe via the Universal Thermal Climate Index (UTCI). International Journal of Biometeorology 62: 1155-1165. DOI 10.1007/s00484-0181518-2.

Nse O.U., Okolie C.J., Nse V.O., 2020. Dynamics of land cover, land surface temperature and NDVI in Uyo Capital City. Nigeria. Scientific African 10: e00599. DOI 0.1016/j. sciaf.2020.e00599.

Nwilo P.C., Olayinka D.N., Obiefuna J.N., Atagbaza A.O., Adzandeh A.E., 2012. Determination of Land Surface Temperature (LST) and potential urban heat island effect in parts of Lagos State using satellite imageries. FUTY Journal of the Environment 7(1), 19-33. DOI 10.4314/fje. v7i1.2.

Obiefuna J.N., Nwilo P.C., Okolie C.J., Emmanuel E.I., Daramola O.E., 2018. Dynamics of land surface temperature in response to land cover changes in Lagos 
metropolis. Nigerian Journal of Environmental Sciences and Technology (NIJEST) 2(2): 148-159. DOI 10.36263/ nijest.2018.02.0074.

Odindi J., Mutanga O., Abdel-Rahman E.M., Adam E., Bangamwabo V., 2017. Determination of urban land cover types and their implication on thermal characteristics in three South African coastal metropolitans using remotely sensed data. South African Geographical Journal 99(1): 52-67. DOI 10.1080/03736245.2015.1117015

Oguz H., 2013. LST calculator: A program for retrieving land surface temperature from Landsat TM/ETM+ imagery. Environmental Engineering and Management Journal 12(3): 549-555. DOI 10.30638/eemj.2013.067.

Ohwo O., Abotutu A., 2015. Environmental Impact of Urbanisation in Nigeria. British Journal of Applied Science $\mathcal{E}$ Technology 9(3): 212-221. DOI 10.9734/bjast/2015/18148.

Ojeh Vincent N., Balogun A.A., Okhimamhe A.A., 2016. Urban-rural temperature differences in Lagos. Climate 4(2): 29. DOI 10.3390/cli4020029.

Ongoma V., Muange P.K., Shilenje Z.W., 2016. Potential effects of urbanization on urban thermal comfort, a case study of Nairobi City, Kenya: A review. Geographica Pannonica 20(1): 19-31.

Orosa J.O., Costa A.M., Rodriguez-Fernandez A., Roshan G., 2014. Effect of climate change on outdoor thermal comfort in humid climates. Journal of Environmental Health Science \& Engineering 12(46): 1-9. DOI 10.1186/2052336X-12-46.

Oyler J.W., Ballantyne A., Jencso K., Sweet M., Running S.W., 2015. Creating a topoclimatic daily air temperature dataset for the conterminous United States using homogenized station data and remotely sensed land skin temperature. International Journal of Climatology 35: 2258-2279. DOI 10.1002/joc.4127.

Parmentier B., McGill B.J., Wilson A.M., Regetz J., Jetz W., Guralnick R., Tuanmu M.N., Schildhauer M., 2015. Using multi-timescale methods and satellite-derived land surface temperature for the interpolation of daily maximum air temperature in Oregon. International Journal of Climatology 35: 3862-3878. DOI 10.1002/joc.4251.

Polydoros A., Cartalis C., 2014. Assessing thermal risk in urban areas - An application for the urban agglomeration of Athens. Advances in Building Energy Research 8: 74-83.

Radeloff V.C., Stewart S.I., Hawbaker T.J., Gimmi U., Pidgeon A.M., Flather C.H., Hammer R.B., Helmers D.P., 2010. Housing growth in and near United States protected areas limits their conservation value. Proceedings of the National Academy of Sciences 107(2): 940-945. DOI 10.1073 / pnas.0911131107.

Richards J., 1999. Remote sensing digital image analysis. Berlin. Springer-Verlag. 240p.

Rizwan A.M., Denis Y.C., Leung L.C., 2008. A review on the generation, determination and mitigation of urban heat island. Journal of Environmental Sciences 20(1): 120-128. DOI 10.1016/s1001-0742(08)60019-4.

Rohat G., Flacke J., Dosio A., Dao H., van Maarseveen M., 2019. Projections of human exposure to dangerous heat in African cities under multiple socioeconomic and climate scenarios. Earth's Future 7: 528-546. DOI 10.1029/2018EF001020.

Setaih K., Hamza N., Mohammed M.A., Dudek S., Townshend T., 2014. CFD modeling as a tool for assessing outdoor thermal comfort conditions in urban settings in hot arid climates. Journal of Information Technology in Construction (ITcon) 19: 248-269.
Seto K.C., Fragkias M., Guneralp B., Reilly M.K., 2011. A meta-analysis of global urban land expansion. PLoS one 6(8): 1-9. DOI 10.1371/journal.pone.0023777.

Shi T., Huang Y., Wang H., Shi C.E., Yang Y.J., 2015. Influence of urbanization on the thermal environment of meteorological station: Satellite-observed evidence. Advances in Climate Change Research 6(1): 7-15. DOI 10.1016/j.accre.2015.07.001

Tarawally M., Wenbo X., Weiming H., Terence D.M., 2018. Comparative analysis of responses of land surface temperature to long-term land use/cover changes between a coastal and inland city: A case of Freetown and Bo town in Sierra Leone. Remote Sensing 10(1): 112. DOI 10.3390/ rs10010112.

Tatem A.J., Nayar A., Hay S.I., 2006. Scene selection and the use of NASA's global orthorectified Landsat dataset for land cover and land use change monitoring. International Journal of Remote Sensing 27: 3073-3078.

Uejio C.K., Wilhelmi O.V., Golden J.S., Mills D.M., Gulino S.P., Samenow J.P., 2011. Intra-urban societal vulnerability to extreme heat: The role of heat exposure and the built environment, socioeconomics, and neighborhood stability. Health Place 17(1): 498-507. DOI 10.1016/j. healthplace.2010.12.005.

Ullah S., Tahir A.A., Akbar T.A., Hassan Q.K., Dewan A., Khan A.J., Khan M., 2019. Remote sensing-based quantification of the relationships between land use land cover changes and surface temperature over the Lower Himalayan Region. Sustainability 11: 5492. DOI 10.3390/ su11195492.

UN [United Nations Department of Economic and Social Affairs, Population Division], 2014. The 2014 Revision World Urbanization Prospects. United Nations, New York. Online: un.org/en/desa/2014-revision-world-urbanization-prospects (accessed 12 March 2020).

UN [United Nations Department of Economic and Social Affairs, Population Division], 2018. The 2018 revision world urbanization prospects. United Nations, New York. Online: un.org/development/desa/publications (accessed 12 March 2020).

USGS [United States Geological Survey], 2015. Landsat 8 (L8) data users handbook, version 1.0. LSDS-1574. Department of the Interior, U.S. Geological Survey.

USGS [United States Geological Surveys], 2020. Global visualisation online portals. Online: glovis.usgs.gov; earthexplorer.usgs.gov/ (accessed 12 March 2020).

Walls W., Parker N., Walliss J., 2015. Designing with thermal comfort indices in outdoor sites. In Crawford R.H., Stephen A. (eds), Living and Learning: Research for a Better Built Environment: 49th International Conference of the Architectural Science Association 2015. 1117-1128. Online: https:/ / anzasca.net/wp-content/uploads/2015/12/107_Walls_ Parker_Walliss_ASA2015.pdf (accessed 19 December 2020).

Wang C., Zhan W., Liu Z., Li J., Li L., Fu P., Huang F., Lai J., Chen J., Hong F., Jiang S., 2020. Satellite-based mapping of the Universal Thermal Climate Index over the Yangtze River Delta urban agglomeration. Journal of Cleaner Production 277: 123830. DOI 10.1016/j.jclepro.2020.123830.

Wei-Wu W., Li-Zhong Z., Ren-Chao W., 2004. An analysis on spatial variation of urban human thermal comfort in Hangzhou, China. Journal of Environmental Sciences 16: 332-338.

Widyasamratri H., Souma K., Suetsugi T., Ishidaira H., Ichikawa Y., Kobayashi H., Inagaki I., 2013. Air temper- 
ature estimation from satellite remote sensing to detect the effect of urbanization in Jakarta, Indonesia. Journal of Emerging Trends in Engineering and Applied Sciences 4: 800-805.

WWO [World Weather Online], 2020. Historical Weather Data. Online: worldweatheronline.com/ (accessed 12 March 2020).

Yahia M.W., Johansson E., Thorsson S., Lindberg F., Rasmussen M.I., 2018. Effect of urban design on microclimate and thermal comfort outdoors in warm-humid Dar es Salaam, Tanzania. International Journal of Biometeorology 62: 373-385. DOI 10.1007/s00484-017-1380-7.

Yilmaz S., 2007. Human thermal comfort over three different land surfaces during summer in the city of Erzurum, Turkey. Atmosfera 20: 289-297.

Yuan F., 2008. Land-cover change and environmental impact analysis in the Greater Mankato area of Minnesota using remote sensing and GIS modeling. International Journal of Remote Sensing 29(4): 1169-1184. DOI 10.1080/01431160701294703

Zare S., Hasheminejad N., Shirvan H. E., Hemmatjo R., Sarebanzadeh K., Ahmadi S., 2018. Comparing Universal Thermal Climate Index (UTCI) with selected thermal indices/environmental parameters during 12 months of the year. Weather and Climate Extremes 19: 49-57. DOI 10.1016/j.wace.2018.01.004.

Zareie S., Khosravi H., Nasiri A., 2016. Derivation of land surface temperature from Landsat Thematic Mapper (TM) sensor data and analysing relation between land use changes and surface temperature. Solid Earth Discussions 1-15. DOI 10.5194/se-2016-22.

Zhang Y., Odeh I.O.A., Han, C., 2009. Bi-temporal characterization of land surface temperature in relation to impervious surface area, NDVI and NDBI, using a sub-pixel image analysis. International Journal of Applied Earth Observation and Geoinformation 11: 256-264.

Zhao S.Q., Da L.J., Tang Z.Y., Fang H.J., Song K., Fang J.Y., 2006. Ecological consequences of rapid urban expansion: Shanghai, China. FrontierEcologyandEnvironment4(7):341346. DOI 10.1890/1540-9295(2006)004[0341:ECORUE]2.0. $\mathrm{CO} ; 2$.

Zhou D., Zhang L., Hao L., Sun G., Liu Y., Zhu C., 2016. Spatiotemporal trends of urban heat island effect along the urban development intensity gradient in China. Science of the Total Environment 544: 617-626. DOI 10.1016/j.scitotenv.2015.11.168. 